\title{
21. GEOCHEMISTRY AND PETROGENESIS OF THE VOLCANIC ROCKS FROM HOLES 768 AND 769, SULU SEA ${ }^{1}$
}

\author{
T. E. Smith, ${ }^{2}$ C. H. Huang, ${ }^{3}$ and F. G. Sajona ${ }^{4}$
}

\begin{abstract}
Major-, trace-, and rare-earth element analyses of the basaltic rocks recovered from the basement of the Sulu Sea and of lithic clasts from the pyroclastic unit representing the acoustic basement of the Cagayan Ridge, are presented. The major and trace elements were measured by X-ray fluorescence techniques, and rare-earth elements by instrumental neutron activation analysis. These data show that the Sulu Sea basalts are back-arc tholeiites and the lithic clasts are basalts, basaltic andesites, and andesites typical of volcanic arc suites erupted on continental crust. Petrogenetic modeling is used to show that the Sulu Sea basalts were derived from a heterogeneous mantle, probably representing subcontinental lithosphere, with contributions from a subduction component. The Sulu Sea is interpreted as a back-arc basin formed by rifting of an Oligocene to early Miocene volcanic arc leaving the Cagayan Ridge as a remnant arc. This event occurred during northward subduction of the Celebes Sea basement beneath the Oligocene to early Miocene arc.
\end{abstract}

\section{INTRODUCTION}

The Sulu Sea is a small ocean basin $600 \mathrm{~km}$ long by $400 \mathrm{~km}$ wide (Fig. 1), and is one of three marginal basins, the Banda, Celebes, and Sulu Seas, located at the junction of the Eurasian, Indo-Australian, and Philippine Sea plates. Lee and McCabe (1986) have suggested that all three marginal basins are trapped fragments of oceanic lithosphere that were once contiguous with the late Jurassic Argo Abyssal Plain off northwest Australia. Rangin (1989), however, has suggested that the Sulu Sea is a back-arc basin that opened in middle Miocene time during subduction of the Celebes Sea Plate. This lack of agreement on the origin of the Sulu Sea is the result of difficulties in interpreting the complex geology of the surrounding islands and the late Cenozoic tectonic evolution of the area. The major objectives of Leg 124 of the Ocean Drilling Program include the establishment of the age and nature of the oceanic basement of the Sulu Sea to clarify the tectonic evolution of the area.

The mineralogical, petrographic, and chemical data of the basement rocks of Holes 768 and 769 Sulu Sea (Shipboard Scientific Party, 1990, Hole 768 Tables 16, 17, 18, 19, and 20, Hole 769 Tables 4,5 , and 6) supplemented by additional major-, trace-, and rare-earth element analyses, are summarized herein. The environments in which these volcanic rocks formed are suggested by comparing their petrography and geochemistry with those of modern basalt and andesite suites that were erupted in known thermotectonic environments (Holm, 1985). The data derived from the study of the clasts from Hole 769 are used to establish the eruption environment that existed in this area immediately prior to the opening of the Sulu Sea. This information, together. with the conclusions drawn about the nature of the basement of the Sulu Sea and the stratigraphy, sedimentology, and paleontol-

\footnotetext{
${ }^{1}$ Silver, E. A., Rangin, C., von Breymann, M. T., et al., 1991. Proc. ODP, Sci. Results., 124: College Station, TX (Ocean Drilling Program).

${ }^{2}$ Department of Geology, University of Windsor, Windsor, Ontario, N9B 3P4, Canada.

${ }^{3}$ Department of Geology, Laurentian University, Sudbury, Ontario, P3E 2C6. Canada.

${ }^{4}$ Petrolab, Mines and Geosciences Bureau, North Avenue, Diliman, Quezon City, Philippines.
}

ogy of the overlying sediments, is used to try to enhance the understanding of the tectonic evolution of this complex area.

\section{PETROGRAPHY AND GEOCHEMISTRY}

\section{Recovery}

Two holes were drilled to acoustic basement in the Sulu Sea, Hole 768 and Hole 769 . Hole 768 was drilled in the southeast Sulu Basin in $4395 \mathrm{~m}$ of water, where $1046 \mathrm{~m}$ of sedimentary and pyroclastic rocks were penetrated, followed by $222 \mathrm{~m}$ of the basement. Core recovery of the basement in Hole $768 \mathrm{C}$ averaged $39.4 \%$. The basement rocks, which comprise basalts and dolerites (Table 1), were initially subdivided into eight units according to their structure and lithological, mineralogical, and textural characteristics (Shipboard Scientific Party, 1990, Hole 768, Fig. 59, Table 16). However, the geochemical data and the geophysical logs (Shipboard Scientific Party, 1990, Hole 768, Tables 18, 19, and 21, Figs. 60 and 61) show that the homogeneous pillow basalt sequence originally designated as Unit 1 comprises two distinct units. The upper unit ( $73 R 1$ to $75 R 1)$ has lower contents of incompatible elements ( $\mathrm{Ti}, \mathrm{K}, \mathrm{Zr}, \mathrm{Nb}$ and the rare earth elements (REE), Tables 3 and 4), and much lower gamma ray intensities (Shipboard Scientific Party, 1990, Summary Log for Site 768) than the lower unit. Thus the original Unit 1 is divided into Units 1 and 2, and original Units 2 through 8 become Units 3 through 9 in the new subdivision (Table 1).

Hole 769 was drilled on the flank of the Cagayan ridge, a volcanic arc, which may be built upon continental crust (Rangin et al., 1989). Recovery averaged less than $30 \%$. At this site, the acoustic basement comprises a thick unit $(100 \mathrm{~m})$ of lapillistones and tuffs, made up predominantly of volcanic glass together with less abundant, cogenetic, crystals and fine-grained lithic fragments of volcanic rocks.

\section{Sample Description}

The thicknesses and mineralogic and petrographic characteristics of the units identified in the basement of Hole $768 \mathrm{C}$ are summarized in Table 1. For more details of the individual units see Shipboard Scientific Party (1990, Hole 768, pp. 257-262). The rocks are all basalts and comprise mixtures of olivine, plagioclase (An45-85, all plagioclase identifications are optical), clinopyroxene, and glass. They occur as pillow lavas and breccias, 


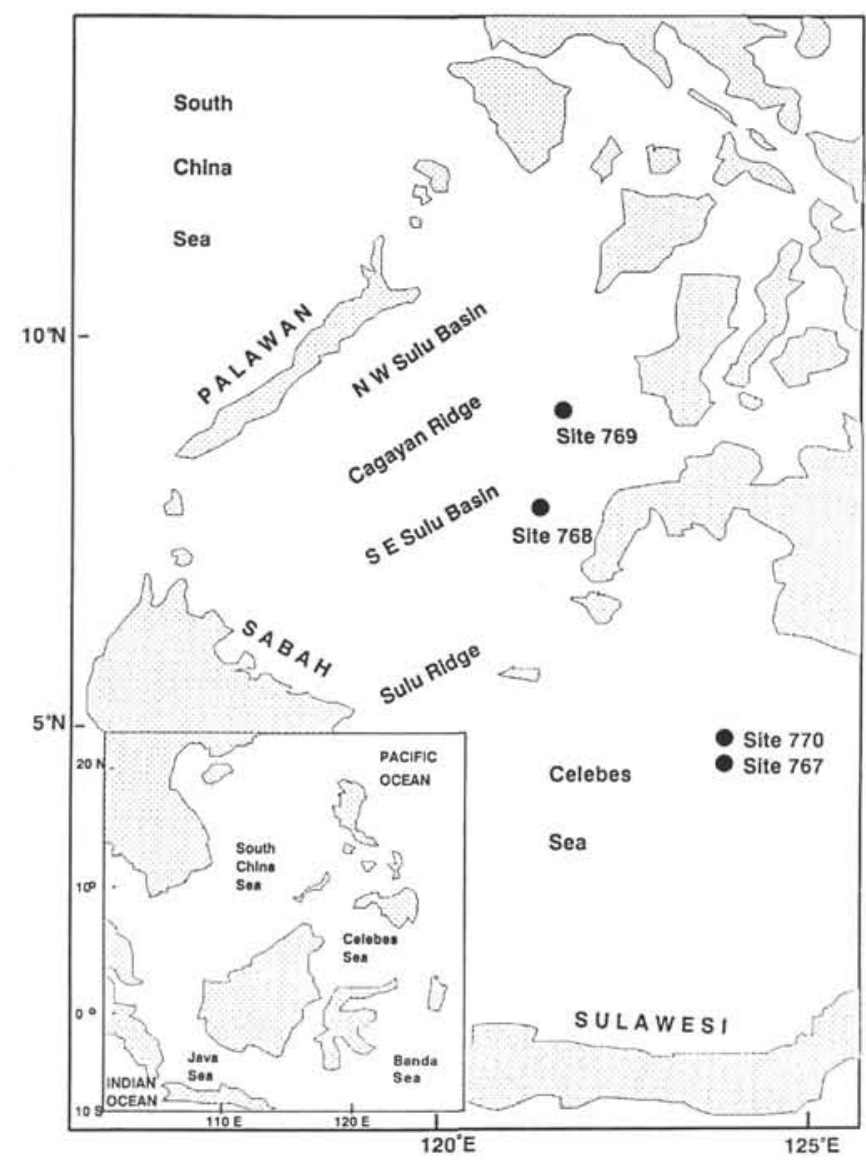

Figure 1. The sites of Holes 768 and 769 , Sulu Sea. Inset shows regional geography and simplified tectonic structure of the area.

massive lavas, and sills. The pillow lavas (Units 1, 2, 5, 7, and 9) are all highly vesicular $(<35 \%)$, fine-grained olivine phyric basalts. Cryptocrystalline to variolitic pillow selvedges, containing quenched skeletal crystals of olivine, are commonly preserved. Pillow interiors are fine-grained, hypocrystalline to holocrystalline, and hyalopilitic, comprising intersertal, intergranular, to sub-ophitic intergrowths of olivine, plagioclase (An50-70), clinopyroxene, and mesostasis. The olivine phenocrysts range in size from $<1.0 \mathrm{~mm}$ to $3.0 \mathrm{~mm}$ and commonly contain euhedral chrome spinel crystals. Vesicles are abundant in all samples. They are spherical, lobate, ovoid, and irregular in shape, and are filled with mixtures of calcite, clay, chalcedony and zeolites. Alteration of the rocks is slight to moderate and involves the complete replacement of the olivine phenocrysts by clay minerals and iron oxide, some devitrification of the glassy mesostasis, and, less commonly, minor replacement of plagioclase by clays and zeolites. The massive lavas (Units 6 and 8 ) are similar in texture and mineralogy to the pillow lavas.

Unit 3 comprises a massive olivine-dolerite sill, $36.50 \mathrm{~m}$ thick, that has an upper chilled margin containing abundant quenched plates of olivine and numerous very small vesicles. The rock is a hypocrystalline to holocrystalline, aphanitic to phaneritic in texture having intersertal, intergranular and sub-ophitic textures. Its mineralogy, vesicle content and filling, and degree and type of alteration, are very similar to those of the lavas. The groundmass plagioclase composition ranges from $\mathrm{An}_{45}$ to $\mathrm{An}_{75}$ (Table 1).

The textures and mineralogical relationships of the units described above indicate that olivine and $\mathrm{Cr}$-spinel, and possibly magnetite, were the liquidus minerals. Following their crystal- lization the remainder of the melt was quenched to yield a mixture of olivine, plagioclase, clinopyroxene, and iron oxide, set in a glassy mesostasis (Table 1). The abundant vesicles (Table 1) indicate that the melts from which these basalts formed were unusually rich in volatiles.

Unit 4 comprises a massive sill of olivine gabbro, estimated to be $19 \mathrm{~m}$ thick, which is mineralogically and texturally unique in the basement sequence. It is a hypocrystalline to holocrystalline rock and is characterized by an intersertal chilled margin grading into fine to medium-grained hypidiomorphic-granular, subophitic and intergranular domains, in the bulk of the intrusion. Mineralogically it comprises intergrowths of olivine, plagioclase (An75-85), and clinopyroxene, together with minor amounts of orthopyroxene, hornblende, phlogopite, and mesostasis. The rock is very much less vesicular than the remainder of the sequence $(<5 \%)$, and where vesicles do occur they are filled with clays. Patches and reticulating networks of clay minerals, including chlorite and illite, replace the primary minerals (Table 1). The extended range of minerals and the textures of this unit point to fractionation in situ, rather than an evolutionary history involving fractional crystallization followed by quenching. The presence of hornblende and biotite, and the lack of vesicles, indicate that the volatiles were retained within the unit during crystallization rather than lost during emplacement.

Unit 4 is treated separately from the remainder of the sequence because of its different mineralogy, textures, and crystallization history. Its mineral paragenesis (olivine, clinopyroxene, plagioclase, orthopyroxene, hornblende, phlogopite) is indicative of the crystallization conditions. Experiments using a picritic basalt (Ulmer, 1988, Table 3), very similar in bulk composition (Mgnumber 76, Cr $1600 \mathrm{ppm}, \mathrm{Ni} 400 \mathrm{ppm}$ ) to Unit 4, show that orthopyroxene crystallizes after olivine, plagioclase, and clinopyroxene at pressures of approximately $6 \mathrm{~kb}$ (Ulmer, 1988, Fig. 16). If orthopyroxene forms before plagioclase the pressure implied is higher. The volatiles present in the melt would be unable to escape at such high pressure which would lead to the formation of hornblende and phlogopite in the unit. There are less than $150 \mathrm{~m}$ of basaltic rocks overlying Unit 4 and the water depth at the time of its emplacement was probably $<5 \mathrm{~km}$ (presently $4.5 \mathrm{~km}$ ). The maximum probable pressure that could have prevailed if Unit 4 was intruded, at its present level, along with the eruption of the other basement units, or at any time to the present, would be $<1.5$ $\mathrm{kb}$ ( $150 \mathrm{~m}$ of basalts, $1000 \mathrm{~m}$ of sediments, $4.5 \mathrm{~km}$ water). The mineral paragenesis of Unit 4 implies that crystallization of much of the melt from which it was formed took place at 6-kb pressure prior to emplacement at the present level. No mineral banding or other evidence of fractional crystallization was noted during the core description (Shipboard Scientific Party, 1990, Section 3 Cores, Site 768 pp.676-684).

Eight samples of the fresh, homogeneous, lithic fragments that occur in the basement lapillistones and tuffs in Hole 769C, were examined petrographically (Shipboard Scientific Party, 1990, Hole 769, Table 4). Their mineralogical and petrographic characteristics are summarized in Table 2. The lithic fragments are moderately to highly porphyritic $(10 \%-50 \%)$ and contain various mixtures of olivine, plagioclase, clinopyroxene, orthopyroxene, and magnetite (Table 2). Plagioclase is the most abundant phenocryst $(5 \%-35 \%)$ in all samples, and shows pronounced oscillatory zoning in the basalts (An65-90) and in the basaltic andesite (An35-85). The groundmass varies from an intersertal to hyalopilitic mixture of plagioclase, clinopyroxene, Fe-Ti oxides, apatite, and glass (Table 2).

\section{Methods}

Thirty-five rocks from the basement of Hole 768 and six lithic fragments from the basement in Hole 769 were analyzed by X-ray 
Unit 1 Estimated thickness $10.30 \mathrm{~m}$ in Hole $768 \mathrm{C}$ (base at $7 \mathrm{R}-1,62 \mathrm{~cm}$ ).

Moderately to Highly Olivine Phyric Pillow Basalt Lavas and Breccias.

Hypocrystalline to Holocrystalline, fine-grained, variolitic, intersertal to intergranular.

\section{PHENOCRYSTS}

$$
\text { Size mm Composition }
$$

$\begin{array}{ll}\text { Olivine } & <1.5 \\ \text { Plagioclase } & \end{array}$

Clinopyroxene

Mesostasis

\section{GROUNDMASS}

$$
\begin{array}{r}
\text { Percent } \\
\text { 5-15 }
\end{array}
$$

$5-15$

Composition
Percentage

$5-40$
$0-25$
$<30$
$15-40$

VESICLES/AMYGDALES

Size $\mathrm{mm}$

$0.02-2.5$

Shape

Filling

Percentage

Spherical

Lobate

Irregular

Elongate
Clay

Iron Oxide
$15-30$

Unit 2 Estimated thickness $91.00 \mathrm{~m}$ in Hole $768 \mathrm{C}$ (base at $88 \mathrm{R}-2,50 \mathrm{~cm}$ ).

Moderately to Highly Olivine Phyric Pillow Basalt Lavas and Breccias.

Holocrystalline to Hypocrystalline, cryptocrystalline to fine-grained, variolitic, intersertal, intergranular.

PHENOCRYSTS

$$
\text { Size mm Composition Per }
$$

$\begin{array}{ll}\text { Olivine } & <3.0 \\ \text { Plagioclase } & \end{array}$

Clinopyroxene

Mesostasis
GROUNDMASS

$$
\begin{gathered}
\text { Percentage } \\
0-12
\end{gathered}
$$

Composition

Percentage

An50-70

$0-4$
$0-40$
025
$20-40$

VESICLES/AMYGDALES Shape Filling

$0.01-2.0$

Spherical

Spherical
Lobate

Irregular

Clay, Calcite

Unit 3 Estimated thickness $36.50 \mathrm{~m}$ (base at top of $92 \mathrm{R}-1$ ).

Massive Olivine Dolerite Sill, upper chilled margin with small vesicles.

Holocrystalline, aphanatic to phaneritic, intergranular, and sub-ophitic.

PHENOCRYSTS

$$
\text { Size mm Composition }
$$

Olivine

Plagioclase

$$
0.25-1.3
$$

Clinopyroxene

Mesostasis

\section{GROUNDMASS}

\begin{abstract}
Percentage
\end{abstract}
$0-15$

Composition
Percentage

\section{5-55}

$0-30$

$10-30$

Percentage

1-35

\section{An45-80}

$10-30$

\begin{tabular}{cccc}
\multicolumn{4}{c}{ VESICLES/AMYGDALES } \\
Size mm & Shape & Filling & Percentage \\
$0.2-5$ & $\begin{array}{c}\text { Spherical } \\
\text { Lobate } \\
\text { Ovoid }\end{array}$ & $\begin{array}{c}\text { Iron Oxide } \\
\text { Calcite, Clay } \\
\text { Zeolites }\end{array}$ & $5-15$ \\
& Z &
\end{tabular}

Unit 4 Estimated thickness $19.00 \mathrm{~m}$ (base at top of $95 \mathrm{R}-1$ ).

Massive Olivine Microgabbro Sill with very few vesicles.

Holocrystalline to Hypocrystalline, hypidiomorphic-granular, fine- to medium-grained, intersertal, sub-ophitic, ophitic.

PHENOCRYSTS

$$
\text { Size mm Composition Percentage }
$$

Olivine

Plagioclase

Clinopyroxene

Orthopyroxene

Hornblende

Biotite

Mesostasis
GROUNDMASS

$\begin{array}{cc}13-20 \\ \text { An75-85 } & 35-50 \\ & 25-30 \\ 5-10 \\ <3 \\ <20 \\ <10\end{array}$

Unit 5 Estimated thickness $37.40 \mathrm{~m}$ (base at top of 95R-1).

Aphyric to Sparcely Olivine Phyric Pillow Lavas and Breccias.

Hypocrystalline, fine-grained, intersertal, intergranular, and sub-ophitic.

PHENOCRYSTS

$$
\text { Size mm Composition Percentage }
$$

Olivine

Plagioclase

Clinopyroxene

$1.0-2.0$

Mesostasis
GROUNDMASS

$0-10$

Composition

$$
\text { An60-70 }
$$$$
\begin{aligned}
& 0-40 \\
& 5-40 \\
& 0-35 \\
& 5-65
\end{aligned}
$$

VESICLES/AMYGDALES

Shape Filling

Spherical

Clay

Percentage

$$
<2.0
$$

Spherical

Unit 6 Estimated thickness $8.45 \mathrm{~m}$ (base at 9 9R-1, $15 \mathrm{~cm}$ ).

Sparcely Olivine Phyric Basalt, massive lava flow.

Hypocrystalline, fine-grained, intersertal.

\section{PHENOCRYSTS}

$\begin{array}{lcc} & \text { Size mm } & \text { Composition } \\ \text { Olivine } & 1-2 & \\ \begin{array}{l}\text { Plagioclase } \\ \text { Clinopyroxene } \\ \text { Mesostasis }\end{array} & & \end{array}$

\section{GROUNDMASS}

Percentage
Composition

An $50-70$
Percentage
VESICLES/AMYGDALES

$\begin{array}{ccc}\text { Shape } & \text { Filling } & \text { Percentage } \\ \text { Spherical } & \begin{array}{c}\text { Many empty } \\ \text { Calcite } \\ \text { Clay } \\ \text { Chalcedony } \\ \text { Zeolites }\end{array} & \\ & \end{array}$

VESICLES/AMYGDALES Shape Filling Percentage 0.3-4 None 
Table 1 (continued).

Unit 7 Estimated thickness $10.00 \mathrm{~m}$ (base at $100 \mathrm{R}-1,50 \mathrm{~cm}$ ). Sparcely Olivine Phyric Basalt Pillow Lavas and Breccias. Holocrystalline, fine-grained, variolitic, intersertal, intergranular.
PHENOCRYSTS

\begin{tabular}{lccccc} 
PHENOCRYSTS & & & \multicolumn{2}{c}{ GROUNDMASS } \\
& Size mm & Composition & Percentage & Composition & Percentage \\
Olivine & $0.2-1.0$ & & $1-3$ & & $0-17$ \\
$\begin{array}{l}\text { Plagioclase } \\
\text { Clinopyroxene }\end{array}$ & & & An70 & $0-25$ \\
Mesostasis & & & & $<1$ \\
\hline
\end{tabular}

GROUNDMASS

\begin{tabular}{cccc}
\multicolumn{4}{c}{ VESICLES/AMYGDALES } \\
Size $\mathrm{mm}$ & Shape & Filling & Percentage \\
$1-3$ & Pipes & Clays & $25-35$
\end{tabular}

$25-35$

VESICLES/AMYGDALES

Shape Filling Percentage

Spherical Clay

Chalcedony

Carbonate

Unit 9 Estimated thickness is greater than $9.8 \mathrm{~m}$, unit extends to base of hole. Moderately Olivine Phyric Basalt Lavas Pillows and Breccias.

Hypocrystalline, fine-grained, intersertal.

PHENOCRYSTS

Size mm

GROUNDMASS

\begin{tabular}{c} 
Composition Percentage \\
$8-10$ \\
\hline
\end{tabular}

GROUNDMASS

Composition Percentage
$0-2$
$25-50$
$2-20$
$15-40$
GROUNDMASS

$$
\begin{aligned}
& 25-30 \\
& 10-25 \\
& 15-40
\end{aligned}
$$

\begin{tabular}{cccc}
\multicolumn{3}{c}{ VESICLES/AMYGDALES } & \\
Size $\mathrm{mm}$ & Shape & Filling & Percentage \\
$0.5-6$ & Spherical & Clay & $<5$ \\
& & & \\
& & & \\
& &
\end{tabular}

fluorescence techniques, on board ship and at Laurentian University, for their major- and trace-element contents. Seven representative samples of the basement in Hole 768 were analyzed for their REE contents using instrumental neutron activation analysis by X-Ray Assay Laboratories in Toronto. Details of the shipboard analytic methods are given in Shipboard Scientific Party (1990, pp. 28-29). The analysis of six lithic fragments was repeated at Laurentian University using a Phillips PW1400 X-ray Spectrometer, as a check on the precision of the shipboard analysis. Full details of the methods are given in Abbott and Smith (1978) and Huang and Smith (1983) for XRF, and Peck and Smith (1989) for XRF and INAA.

The precisions of the Laurentian determinations, calculated using the average standard deviation of several replicate analyses for each element, are major elements $0.2 \%$ and trace elements $5 \%$. The precisions of the REE determinations, calculated in the same manner, are $5 \%$ for $\mathrm{La}, \mathrm{Nd}, \mathrm{Sm}, \mathrm{Eu}, \mathrm{Tb}, \mathrm{Yb}$ and $\mathrm{Lu}$, and $10 \%$ for $\mathrm{Ce}$. The major element analyses determined at Laurentian University are in good agreement with those determined on board ship with the one exception. $\mathrm{P}_{2} \mathrm{O}_{5}$ is systematically lower than the shipboard analyses by approximately $15 \%$ (cf. Shipboard Scientific Party, 1990, Hole 769 Table 5, and Table 3 this paper). The majority of the Laurentian trace-element analyses agree with those determined on board ship within two standard deviations for samples from the same units. For $\mathrm{Cr}, \mathrm{Ni}$, and $\mathrm{Ba}$, shipboard analyses are of the same general magnitude but are systematically lower; however, the differences are not large enough to affect the interpretation of the data. The shipboard $\mathrm{Ce}$ analyses are considered to be unreliable because they differ randomly from the Laurentian analyses and do not vary systematically within the rock suite. (Tables 4 and 5, and Shipboard Scientific Party, 1990,
Hole 768 Table 19). The Ce analyses used in the discussion below were all determined by INAA (Table 6 ).

\section{Alteration}

All of the samples collected from Hole $768 \mathrm{C}$ have undergone some degree of alteration of their original mineralogy (Table 1, and Shipboard Scientific Party, 1990, Hole 768 Table 6). They may also be expected to have undergone some alteration of their original chemical composition. The analyses have unusually high loss on ignition (LOI) values (commonly 6.0\%; Table 3 and Shipboard Scientific Party, 1990, Hole 768, Table 18), which may be indicative of post-solidification alteration. However, if these basalts formed in a back-arc basin environment their higher than average volatile contents could be original (Saunders and Tarney, 1984, Rauterschlien et al., 1985). The graphical method developed by Beswick and Soucie (1978) has been used to evaluate which of the major element concentrations have been altered and which have not. This method shows (Fig. 2, see caption for explanation) that there have been increases in the original $\mathrm{K}_{2} \mathrm{O}$ contents, decreases in the original $\mathrm{Na}_{2} \mathrm{O}$ contents, and possibly minor decreases in the $\mathrm{CaO}$ contents. The remainder of the major element contents are relatively unchanged. The $\mathrm{Rb}, \mathrm{Ba}, \mathrm{Th}, \mathrm{U}$, and $\mathrm{Sr}$ contents do not vary systematically with $\mathrm{Zr}$, nor do they show regular distribution on multielement plots. This suggests that they may have been mobile during the mineralogical alteration and that their original concentrations have not been preserved. The $\mathrm{Na}_{2} \mathrm{O}, \mathrm{K}_{2} \mathrm{O}, \mathrm{CaO}$, and $\mathrm{Rb}, \mathrm{Ba}$, Th, $\mathrm{U}$, and $\mathrm{Sr}$ contents are not used to classify the rocks or to model their petrogenesis. The Nb, Y, P, Ti, Ni, Cr, Sc, and REE contents, except Ce, vary systematically with $\mathrm{Zr}$ and plot in consistent patterns on multielement plots (Figs. 3, 4, and 5). This suggests that, as noted pre- 
Table 2. Mineralogy, petrography, major-element chemistry, and normative mineralogical compositions of lithic clasts from Hole 769, Sulu Sea.

\begin{tabular}{|c|c|c|c|c|c|c|c|c|}
\hline $\begin{array}{l}\text { Core-sec } \\
\text { Interval }(\mathrm{cm})\end{array}$ & $\begin{array}{c}3 R-2 \\
41-43\end{array}$ & $\begin{array}{l}4 R-5 \\
9-15\end{array}$ & $\begin{array}{c}5 R-5 \\
22-25\end{array}$ & $\begin{array}{c}7 \mathrm{R}-1 \\
108-112\end{array}$ & $\begin{array}{c}9 \mathrm{R}-3 \\
116-120\end{array}$ & $\begin{array}{c}9 R-4 \\
46-49\end{array}$ & & \\
\hline Lithology & basalt & basalt & $\begin{array}{l}\text { basaltic } \\
\text { andesite }\end{array}$ & $\begin{array}{l}\text { basaltic } \\
\text { andesite }\end{array}$ & andesite & basalt & IAB & $\mathrm{CAB}$ \\
\hline \multicolumn{9}{|c|}{ MAJOR ELEMENT CONTENTS (WT \%) } \\
\hline $\mathrm{SiO}_{2}$ & 49.31 & 50.21 & 54.92 & 56.10 & 57.41 & 52.34 & 51.70 & 51.60 \\
\hline $\mathrm{TiO}_{2}$ & 0.63 & 1.16 & 0.99 & 0.89 & 0.89 & 0.97 & 0.85 & 1.00 \\
\hline $\mathrm{Al}_{2} \mathrm{O}_{3}$ & 17.76 & 18.25 & 18.59 & 17.51 & 16.41 & 19.56 & 17.50 & 17.40 \\
\hline $\mathrm{Fe}_{2} \mathrm{O}_{3}$ & 8.97 & 9.00 & 7.32 & 7.59 & 7.36 & 7.20 & 10.45 & 10.11 \\
\hline $\mathrm{MnO}$ & 0.12 & 0.14 & 0.11 & 0.15 & 0.15 & 0.16 & 0.18 & 0.18 \\
\hline $\mathrm{MgO}$ & 7.48 & 5.14 & 3.61 & 3.98 & 3.33 & 4.18 & 7.00 & 6.80 \\
\hline $\mathrm{CaO}$ & 10.06 & 8.94 & 7.67 & 8.08 & 7.00 & 8.76 & 10.20 & 9.70 \\
\hline $\mathrm{Na}_{2} \mathrm{O}$ & 2.35 & 2.84 & 3.49 & 2.95 & 3.08 & 3.33 & 2.60 & 2.70 \\
\hline $\mathrm{K}_{2} \mathrm{O}$ & 0.61 & 1.81 & 1.61 & 1.22 & 1.53 & 1.81 & 0.49 & 1.20 \\
\hline $\mathrm{P}_{2} \mathrm{O}_{5}$ & 0.34 & 0.31 & 0.25 & 0.20 & 0.18 & 0.36 & 0.09 & 0.30 \\
\hline $\mathrm{Mg} \#$ & 65.55 & 56.63 & 52.97 & 54.53 & 50.78 & 57.01 & 60.00 & 60.00 \\
\hline LOI & 3.54 & 2.81 & 1.96 & 1.54 & 1.14 & 1.66 & & \\
\hline \multicolumn{9}{|c|}{ NORMATIVE MINERAL COMPOSITION (\%) } \\
\hline Q & & & 2.82 & 8.66 & 10.89 & 0.75 & 0.68 & \\
\hline Or & 3.86 & 11.44 & 10.16 & 7.73 & 9.64 & 11.48 & 2.91 & 7.12 \\
\hline $\mathrm{Ab}$ & 20.29 & 25.35 & 32.67 & 25.42 & 28.91 & 26.53 & 23.46 & 24.33 \\
\hline An & 36.77 & 31.68 & 29.38 & 32.01 & 25.90 & 34.59 & 34.83 & 31.96 \\
\hline Di & 11.08 & 10.13 & 7.17 & 6.53 & 7.17 & 6.56 & 12.35 & 11.49 \\
\hline $\mathrm{Hy}$ & 19.28 & 9.42 & 13.95 & 15.81 & 13.70 & 15.80 & 23.09 & 20.04 \\
\hline Ol & 4.82 & 7.05 & & & & & & 1.75 \\
\hline Mt & 1.91 & 1.89 & 1.49 & 1.56 & 1.55 & 1.51 & 1.31 & 1.26 \\
\hline II & 1.16 & 2.24 & 1.87 & 1.71 & 1.73 & 1.84 & 1.19 & 1.40 \\
\hline Ap & 0.84 & 0.81 & 0.49 & 0.57 & 0.51 & 0.92 & 0.19 & 0.64 \\
\hline
\end{tabular}

MODAL MINERAL COMPOSITION \%

Phenocrysts

\begin{tabular}{lrrrcrl} 
Olivine & 4 & 8 & & 2 & 1 & 5 \\
$\begin{array}{l}\text { Plagioclase } \\
\text { Clinopyroxene }\end{array}$ & 25 & 15 & 30 & 30 & 25 & 35 \\
$\begin{array}{l}\text { Orthopyroxene } \\
\text { Magnetite }\end{array}$ & & 1 & 6 & 10 & 6 & 8 \\
$\quad$ & & tr & 3 & 4 & 4 & 3 \\
Groundmass & & & & & & \\
& & & & & & \\
Percentage & 60 & 72 & 60 & 52 & 54 & 48 \\
Texture & Int & Int & Hyal & Hyal-Pil & Hyal & Hyal \\
Amygdales & 5 & 4 & 1 & 2 & 2 & 1 \\
\hline
\end{tabular}

Abbreviations: Int-Intersertal, Hyal-Hyalopilitic, Pil-Pilotaxitic, IAB, island arc basalt; CAB, calc-alkaline basalt from Condie, 1985; andesite, average circum-Pacific andesite from Taylor, 1969.

viously by Condie (1981), Gelinas et al. (1982), Ludden et al. (1982), Kokelaar et al. (1984), Pearce et al. (1984), Saunders and Tarney (1984), and Condie et al. (1985), these elements have been relatively immobile during alteration. Their original concentrations may be diluted slightly by the introduction of volatiles, but their ratios remain unchanged. They are used, together with $\mathrm{SiO}_{2}$, $\mathrm{Al}_{2} \mathrm{O}_{3}$, and $\mathrm{Fe}_{2} \mathrm{O}_{3}$, in classifying the rocks and evaluation their petrogenesis.

The lithic fragments which were analyzed from the basement of Hole 769 , all have low loss on ignition (generally $<2.0 \%$, Table 2 ). However, they show slight to moderate alteration, principally the replacement of olivine by clays and iron oxides and the oxidation of the glassy mesostasis. The chemical data available for these rocks is insufficient to evaluate the effects of chemical alteration, and they are classified and evaluated in the same manner as the basalts from Hole 768 .

Many Sulu Sea samples show negative Ce anomalies on multielement plots. Three suites may be recognized; those with prominent negative $\mathrm{Ce}$ anomalies (Figs. $4 \mathrm{a}$ and $5 \mathrm{a}$ ), those with minor negative $\mathrm{Ce}$ anomalies (Figs. 4B and 5B), and those without
Ce anomalies (Figs. 4C and 5C). The other REE show the same distribution patterns in all three suites (Figs. 4 and 5). These relationships indicate that $\mathrm{Ce}$ has been preferentially fractionated from the other REE. Such fractionation can only occur under the oxidizing conditions of near-surface environments (Meen, 1990) where Ce can form a tetravalent ion but the other REE remain trivalent. The significance of the negative $\mathrm{Ce}$ anomalies is discussed below.

\section{Classification}

All of the samples recovered from the basement of Hole 768 (see Appendix) are basalts ( $<52 \% \mathrm{SiO}_{2}$, Le Maitre, 1976), with the exception of $3.1,3.3$, and 5.2 , which are basaltic andesites $\left(52 \%-56 \% \mathrm{SiO}_{2}\right)$ (Table 3, and Shipboard Scientific Party, 1990, Hole 768 Table 18$)$. The average $\mathrm{Nb} / \mathrm{Y}$ ratios $(<0.14$, Table 4$)$ show these rocks are sub-alkaline in composition (Floyd and Winchester, 1978). All of the basement units are olivine tholeiites in average normative mineral composition (Table 3). Two samples were left out of the averages presented to avoid giving misleading impressions of the composition of the two units. They 
Table 3. Major-element chemistry and normative mineralogy of the basaltic rocks from Hole 768, Sulu Sea.

\begin{tabular}{|c|c|c|c|c|c|c|c|c|c|c|}
\hline $\begin{array}{l}\text { Core-Section } \\
\text { Interval (cm) } \\
\text { Unit. Sample \# }\end{array}$ & 1.Av & 2.Av & 3.Av & 4.Av & 5.Av & $\begin{array}{c}98 \mathrm{R}-3 \\
69-72 \\
6.1\end{array}$ & 8.Av & N-MORB & $\mathrm{CAB}$ & IAB \\
\hline \multicolumn{11}{|c|}{ MAJOR ELEMENT CONTENTS (WT \%) } \\
\hline $\mathrm{SiO}_{2}$ & 48.57 & 49.84 & 51.05 & 48.62 & 51.39 & 50.39 & 50.37 & 51.50 & 51.60 & 51.70 \\
\hline $\mathrm{TiO}_{2}$ & 0.82 & 1.03 & 1.04 & 0.77 & 1.07 & 1.14 & 1.08 & 1.60 & 1.00 & 0.85 \\
\hline $\mathrm{Al}_{2} \mathrm{O}_{3}$ & 15.64 & 16.60 & 17.00 & 13.21 & 15.45 & 18.11 & 15.37 & 16.20 & 17.40 & 17.50 \\
\hline $\mathrm{Fe}_{2} \mathrm{O}_{3}$ & 9.33 & 9.91 & 8.79 & 10.46 & 9.49 & 10.10 & 10.20 & 9.78 & 10.11 & 10.45 \\
\hline Mno & 0.23 & 0.19 & 0.19 & 0.16 & 0.29 & 0.21 & 0.21 & 0.18 & 0.18 & 0.18 \\
\hline $\mathrm{MgO}$ & 13.38 & 11.10 & 8.09 & 16.81 & 10.17 & 8.62 & 8.05 & 6.50 & 6.80 & 7.00 \\
\hline $\mathrm{CaO}$ & 9.45 & 7.95 & 9.86 & 8.37 & 7.50 & 7.35 & 10.41 & 11.90 & 9.70 & 10.20 \\
\hline $\mathrm{Na}_{2} \mathrm{O}$ & 1.82 & 2.26 & 3.19 & 1.23 & 2.95 & 3.56 & 3.24 & 3.00 & 2.70 & 2.60 \\
\hline $\mathrm{K}_{2} \mathrm{O}$ & 0.58 & 1.18 & 0.65 & 0.07 & 1.42 & 1.35 & 0.97 & 0.12 & 1.20 & 0.49 \\
\hline $\mathrm{P}_{2} \mathrm{O}_{5}$ & 0.16 & 0.19 & 0.15 & 0.12 & 0.18 & 0.18 & 0.16 & 0.16 & 0.30 & 0.09 \\
\hline Mg\# & 76.54 & 71.65 & 67.71 & 78.50 & 70.43 & 66.00 & 64.28 & 60.00 & 60.00 & 60.00 \\
\hline LOI & 7.17 & 6.81 & 3.59 & 5.55 & 5.08 & 6.48 & 4.97 & & & \\
\hline \multicolumn{11}{|c|}{ NORMATIVE MINERAL COMPOSITION (\%) } \\
\hline Or & 3.46 & 7.03 & 3.86 & 0.41 & 8.49 & 7.94 & 5.76 & 0.71 & 7.12 & 2.91 \\
\hline$A b$ & 15.54 & 19.20 & 27.11 & 10.54 & 25.12 & 30.04 & 24.64 & 27.11 & 24.33 & 23.46 \\
\hline An & 33.00 & 31.82 & 30.38 & 30.57 & 24.93 & 29.38 & 29.75 & 30.61 & 31.96 & 34.83 \\
\hline $\mathrm{Di}$ & 10.68 & 5.44 & 14.62 & 8.55 & 9.36 & 4.86 & 21.49 & 22.22 & 11.49 & 12.35 \\
\hline Hy & 16.93 & 19.55 & 10.55 & 32.90 & 15.57 & 2.85 & 5.11 & 15.07 & 20.04 & 23.09 \\
\hline OI & 16.60 & 12.61 & 9.46 & 13.19 & 12.20 & 20.35 & 12.22 & & 1.75 & \\
\hline Mt & 1.87 & 1.98 & 1.76 & 2.11 & 1.91 & 2.01 & 2.05 & 1.23 & 1.26 & 1.31 \\
\hline II & 1.56 & 1.96 & 1.92 & 1.48 & 2.06 & 2.17 & 2.06 & 2.24 & 1.40 & 1.19 \\
\hline Ap & 0.36 & 0.41 & 0.33 & 0.26 & 0.39 & 0.40 & 0.35 & 0.34 & 0.64 & 0.19 \\
\hline
\end{tabular}

Abbreviations: (N-MORB, average normal mid-ocean ridge basalt; CAB, calc-alkaline basalt; IAB, island-arc basalt. From Condie, 1985).

Sulu Sea

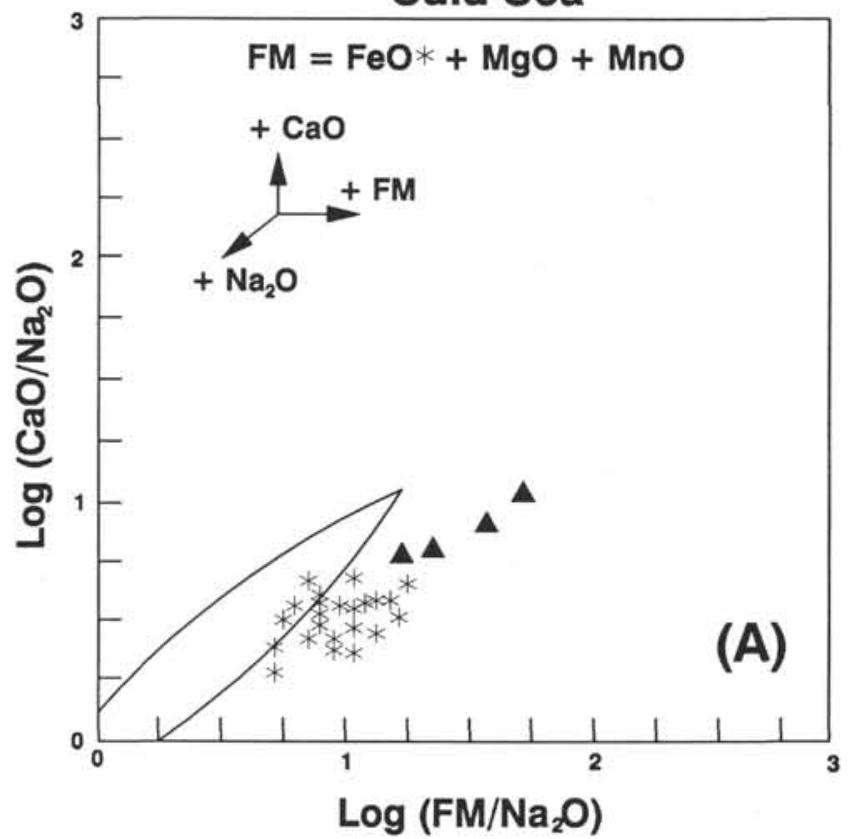

Sulu Sea

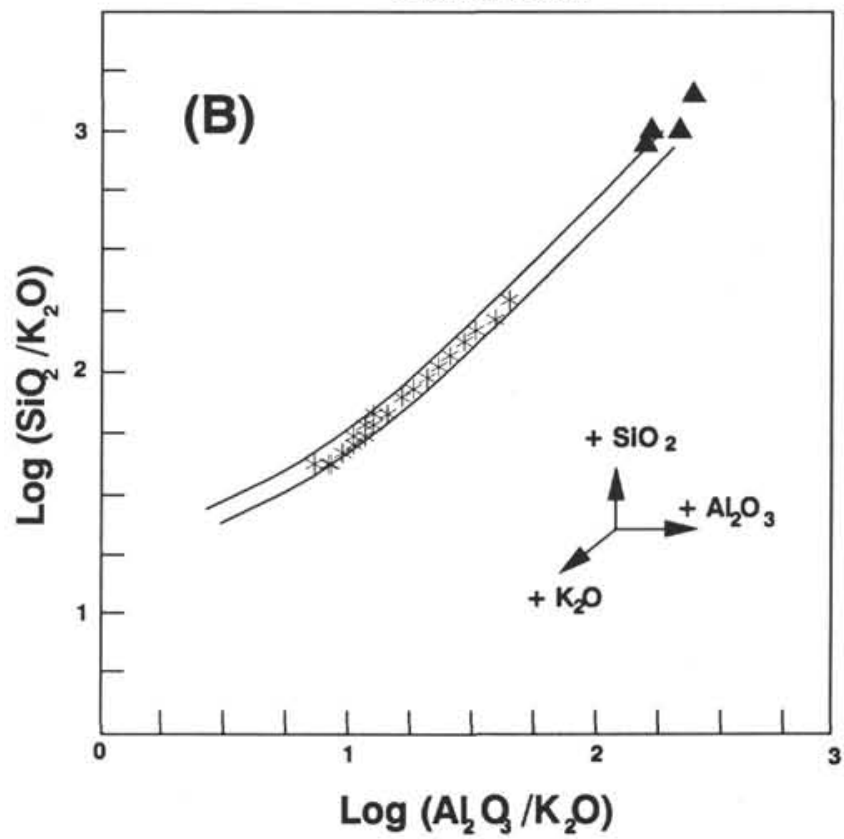

Figure 2. Selected Beswick and Soucie diagrams (1978) illustrating the chemical changes due to alteration of the rocks of Hole 768, Sulu Sea. The boundary curves enclose the fields of unaltered rocks and the arrows represent vectors of secondary enrichment. $\mathrm{A}$. The $\log \left(\mathrm{CaO} / \mathrm{Na}_{2} \mathrm{O}\right)$ vs. $\log \left(\mathrm{FM} / \mathrm{Na}{ }_{2} \mathrm{O}\right)$ plot illustrates the decrease in $\mathrm{Na}_{2} \mathrm{O}$ contents. $\mathrm{B}$. The $\log \left(\mathrm{SiO}_{2} / \mathrm{K}_{2} \mathrm{O}\right)$ vs. $\log \left(\mathrm{AL}_{2} \mathrm{O}_{3} / \mathrm{K}_{2} \mathrm{O}\right)$ plot illustrates the increase in $\mathrm{K}_{2} \mathrm{O}$ contents. 


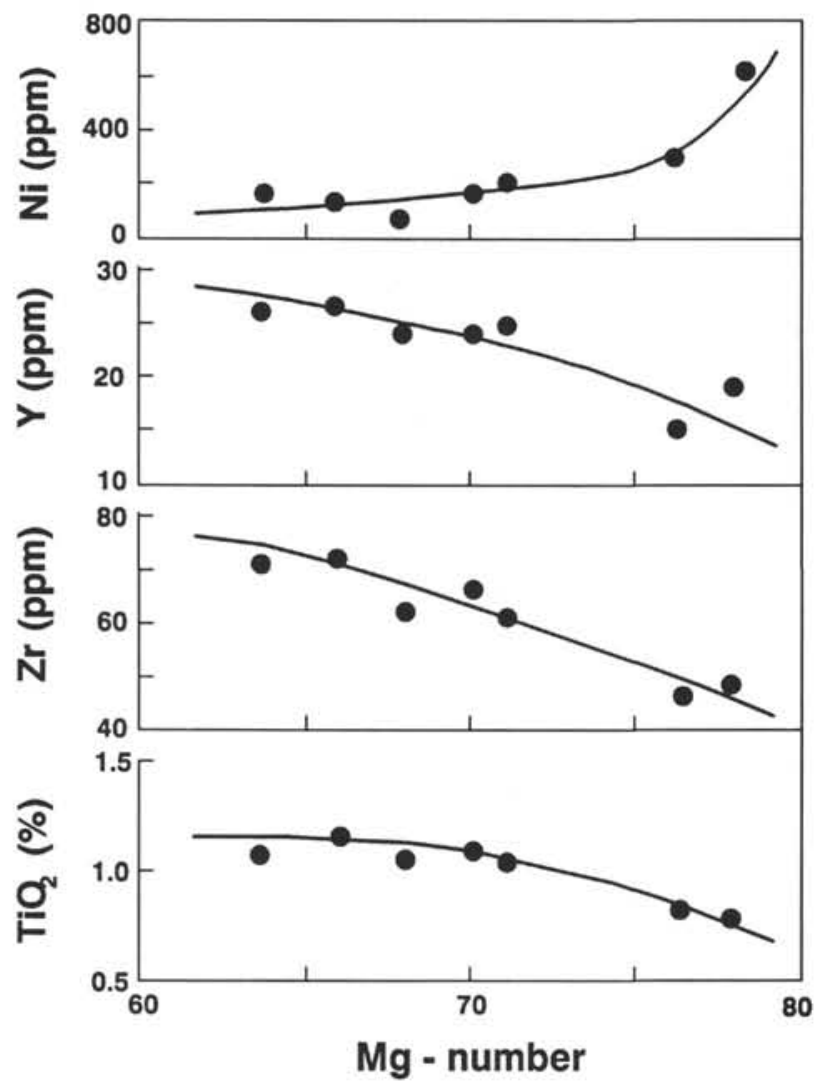

Figure 3. Plot of $\mathrm{TiO}_{2}, \mathrm{Zr}, \mathrm{Y}$, and $\mathrm{Ni}$ contents of the basalts of Hole 768 vs. Mg-numbers.

are Sample 3.3, which is the only quartz-normative basaltic andesite $\left(53.46 \% \mathrm{SiO}_{2}\right)$ in an olivine tholeiitic unit, and Sample 5.3, which is the only nepheline-normative sample in a unit made up of olivine tholeiites. Sample 5.3 has very high contents of $\mathrm{Na}_{2} \mathrm{O}$ and $\mathrm{K}_{2} \mathrm{O}$, which suggest that the rock has undergone significant alkali metasomatism (Shipboard Scientific Party, 1990, Hole 768, Tables 18 and 20 ).

Some of these rocks are picritic in composition, and almost all have high Mg-numbers (65), and are less evolved than typical IAB and MORB (Mg-number 60, Table 3 ). The samples have very high volatile contents but their $\mathrm{Nb}, \mathrm{Y}, \mathrm{P}, \mathrm{Ti}, \mathrm{Ni}, \mathrm{Cr}, \mathrm{Sc}$, and the REE (except Ce) contents are close to their original levels. These element contents and ratios may be used to classify the rocks.

The basalts recovered from the basement may have formed either at a mid-ocean ridge (if the Sulu Sea is a trapped fragment of oceanic lithosphere) or in a back-arc environment (if Sulu Sea formed as a result of back-arc rifting). Some major- and trace-element abundances of back-arc tholeiites (BAT) overlap with those of normal mid-ocean ridges basalts (N-MORB), but typically BAT and island-arc tholeiites (IAT) have higher large-ion lithophile to high field strength element ratios (LIL/HFSE) than $\mathrm{N}$-MORB (Taylor and Karner, 1983). The $\mathrm{TiO}_{2}, \mathrm{Ni}$, and $\mathrm{Cr}$ contents of BAT, are transitional between IAT and N-MORB (Taylor and Karner, 1983). Holm (1985) has compiled a series of multielement diagrams that illustrate the characteristic signatures of tholeiitic basalts and basaltic andesites erupted in different tectonic environments. Thus it may be possible to use the chemical compositions of the basalts discriminate between the two proposed origins.
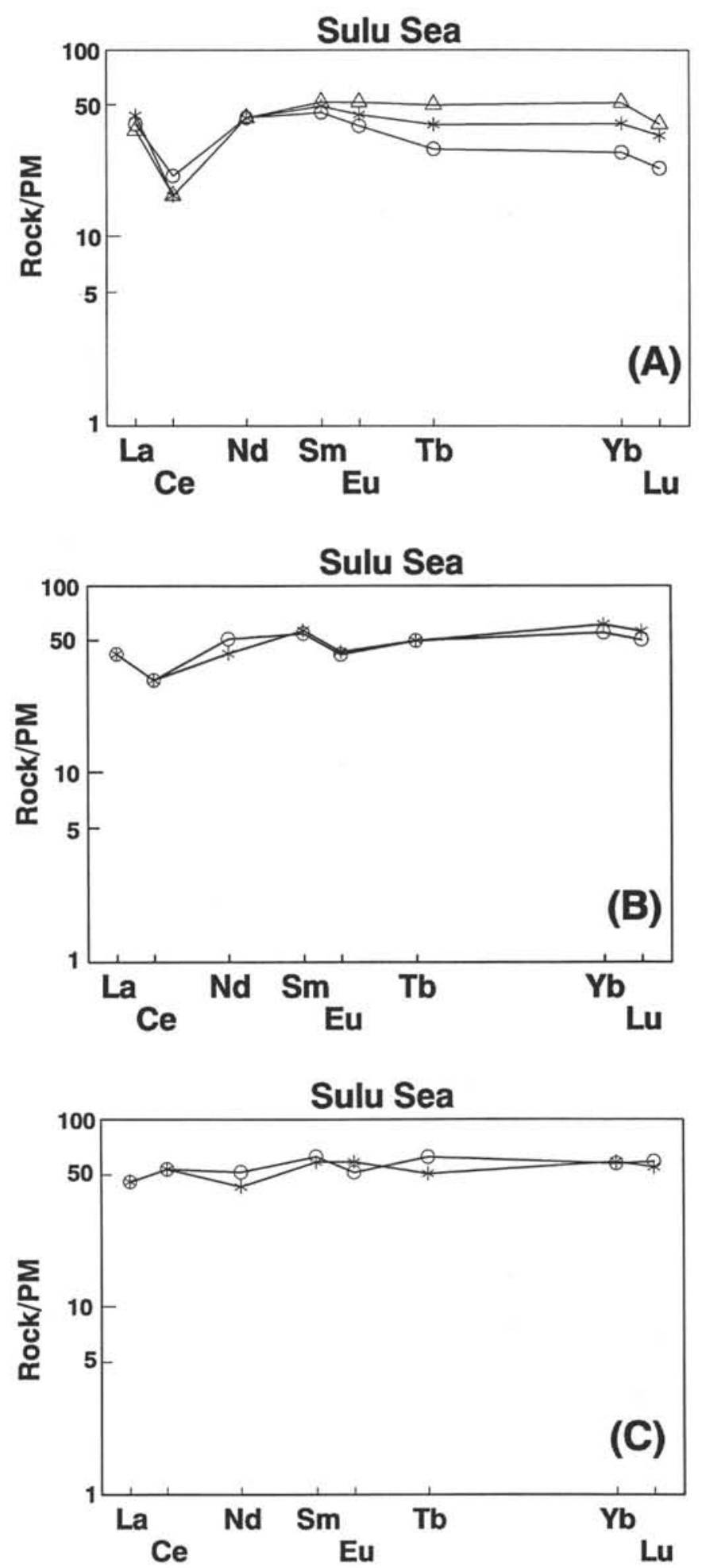

Figure 4. Primordial mantle-normalized (Wood et al., 1979b) rare-earth element plot of basalts from Hole 768, Sulu Sea. A. Samples with prominent negative Ce anomalies. Sample 1.3 (open circle), Sample 2.14 (asterisk), Sample 6.1 (triangle). B. Samples with minor negative $\mathrm{Ce}$ anomalies. Sample 3.2 (asterisk), Sample 4.4 (open circle). C. Samples without Ce anomalies. Sample 5.2 (open circle), Sample 8.2. (asterisk). 

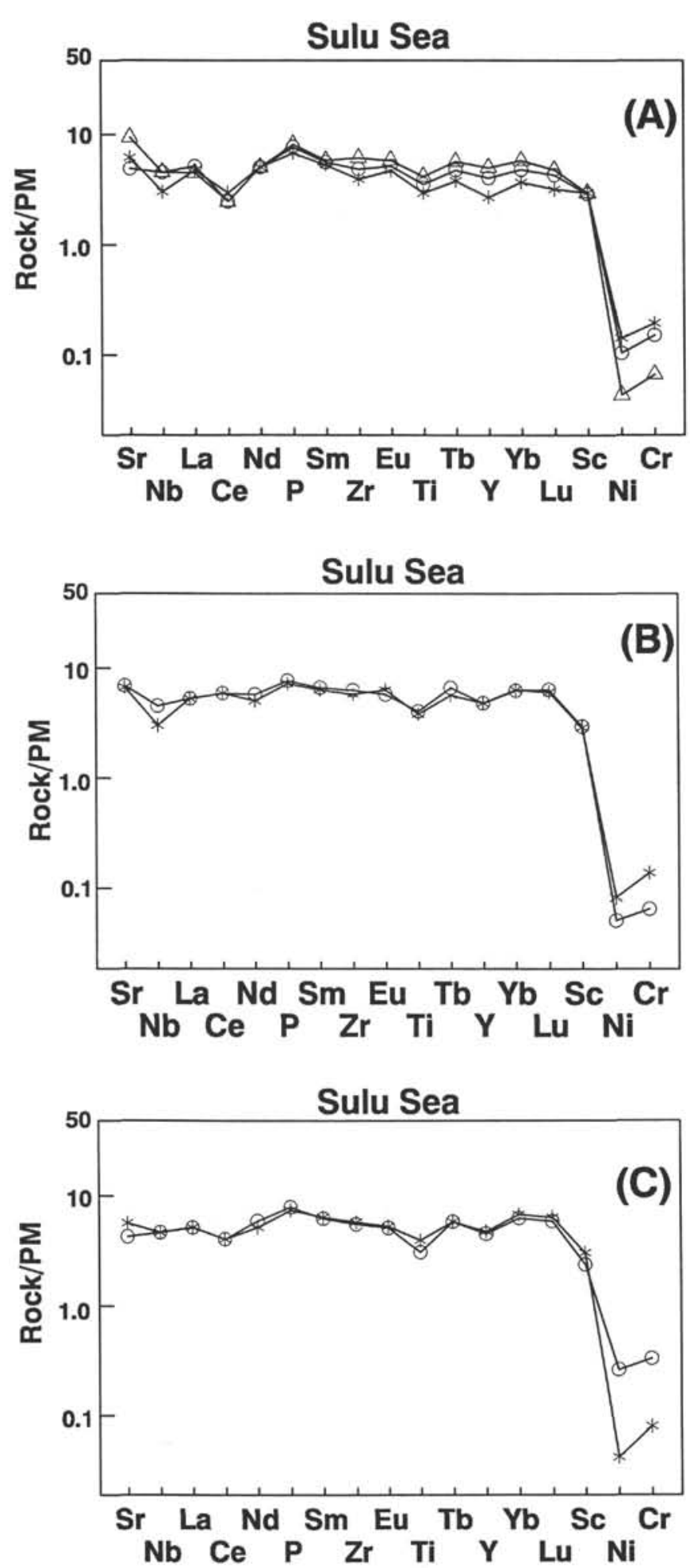

Figure 5. Primordial mantle-normalized multielement plots of basalts from Hole 768C, Sulu Sea. A. Sample 1.3 (open circle), Sample 2.14 (asterisk), Sample 6.1 (triangle). B. Sample 3.2 (asterisk), Sample 4.4 (open circle). C. Sample 5.2 (open circle), Sample 8.2 (asterisk).
Unit 4 has relatively low contents of $\mathrm{TiO}_{2}(0.77 \%), \mathrm{P}_{2} \mathrm{O}_{5}$, $(0.12 \%), \mathrm{Zr}(48 \mathrm{ppm})$ and $\mathrm{Y}(18 \mathrm{ppm})$, and $(\mathrm{La} / \mathrm{Sm}) \mathrm{PM}$ and $(\mathrm{La} / \mathrm{Yb})$ PM ratios, which are similar to those of the other units in the sequence, but has much higher Mg-numbers (78.50), $\mathrm{Ni}$ (612 ppm) and $\mathrm{Cr}(1089 \mathrm{ppm}$ ) contents (Tables 3, 4, and 5). It is considered to have been derived from the same source as the other units, but has had a different crystallization history. The mineral paragenesis suggests that much of the crystallization occurred at pressures of $6 \mathrm{~kb}$ or greater, implying that the sill was intruded at its present level as a crystal mush. Within the sill the $\mathrm{P}_{2} \mathrm{O}_{5}, \mathrm{TiO}_{2}$ and $\mathrm{Zr}$ contents of the samples closest to the top and bottom are higher than they are in samples from the centre of the sill (Shipboard Scientific Party, 1990, Hole 768 Tables 18 and 19). This provides some support for the suggestion, based on textural and mineralogical features, that the sill differentiated in situ, but does not explain the very high $\mathrm{Mg}$-numbers, $\mathrm{Ni}$, and $\mathrm{Cr}$ contents (Shipboard Scientific Party, 1990, Hole 768, Tables 18 and 20). However, if the sill was intruded as a crystal mush, filter pressing during emplacement may have removed some of the interstitial (evolved) melt leading to the formation of rocks characterized by high $\mathrm{Mg}$ - numbers, and $\mathrm{Ni}$ and $\mathrm{Cr}$ contents. Much of the remaining volatile content would 2 be removed with the evolved melt, accounting for the lack of vesiculation in this unit. The composition of Unit 4 is not representative of the original melt from which it was formed. Therefore it is not used to identify the environment of eruption or in the petrogenetic reconstruction.

The Sulu Sea rocks are less evolved than typical N-MORB, $\mathrm{CAB}$, and IAB (Table 3), and have higher $\mathrm{MgO}$ and lower $\mathrm{CaO}$ contents. They show no distinctive major-element features that would allow them to be assigned to one of these characteristic suites.

However, the relatively low $\mathrm{Zr}$ (40 to $65 \mathrm{ppm})$ and $\mathrm{TiO}_{2}(0.8$ to $1.0 \%$ ) contents (Table 3 and 4 ) of the basement rocks imply that they have affinities to arc volcanics. Their trace-element signatures are compared to those of Ocean Floor Tholeiites (OFT, equivalent to N-MORB), back-arc tholeiitic basalts (BAT), lowpotassium tholeiites (LKT) (equivalent of IAB), Ocean Island Tholeiites (OIT), enriched mid-ocean ridge basalt (E-MORB) compiled by Holm (1985) and transitional mid-ocean ridge basalt (T-MORB, Wood et al., 1979a) (Fig. 6, Table 6). Sample 1.3 (Mg-number 76, $\mathrm{Zr} 46 \mathrm{ppm}$ ) the least evolved, and Sample 8.2 (Mg-number $64, \mathrm{Zr} 68 \mathrm{ppm}$ ) the most evolved, of the typical samples analyzed from the Sulu Sea, both have similar traceelement signatures (Table 6). Sample 8.2 is chosen for graphical comparison (Fig. 6) because it is closest to the characteristic suites in $\mathrm{Mg}$-number, and has no negative $\mathrm{Ce}$ anomaly indicating that its original composition is little affected by alteration. Its pattern differs from that of OFT (N-MORB) principally in having a negative $\mathrm{Nb}$ anomaly. The pattern of Sample 8.2 is most similar to those of the LKT and BAT and is intermediate between them in elemental concentrations (Fig. 6a), LKT has lower concentrations and BAT has higher concentrations. All three patterns are relatively flat with light rare-earth element (LREE) and $P$ are slightly enriched in comparison with the high field strength elements (HFSE) and heavy rare earth elements (HREE), and most significantly have negative $\mathrm{Nb}$ anomalies. E-MORB, and OIT patterns have much more fractionated multielement patterns than Sample 8.2, with higher concentrations of $\mathrm{Nb}$ through $\mathrm{Ti}$, and about the same contents of $\mathrm{Tb}, \mathrm{Y}$, and $\mathrm{Yb}$ as Sample 8.2 (Fig. 6b). The T-MORB pattern (Fig. 6b), like that of BAT, is relatively flat and shows slight LREE enrichment but has a positive $\mathrm{Nb}$ anomaly. T-MORB has a much lower $\mathrm{Zr} / \mathrm{Nb}$ ratio (10) than the Sulu Sea basalts do (average $\mathrm{Zr} / \mathrm{Nb} 23$ ) and BAT $(\mathrm{Zr} / \mathrm{Nb} 32$ ) (Table 6). The majority of the samples plot outside the IAT (equivalent to LKT) field and in or near the fields of back-arc basalts on the Cr vs. Y diagram (Pearce et al., 1984). The back-arc field defined on this 
Table 4. Trace-element chemistry and ratios of the basaltic rocks of Hole 768, Sulu Sea.

\begin{tabular}{|c|c|c|c|c|c|c|c|}
\hline $\begin{array}{l}\text { Core-Section } \\
\text { Interval }(\mathrm{cm}) \\
\text { Unit. Sample \# }\end{array}$ & 1.Av & 2.Av & 3.Av & 4.Av & 5.Av & $\begin{array}{c}98 \mathrm{R}-3 \\
69-72 \\
6.1\end{array}$ & 8.Av \\
\hline \multicolumn{8}{|c|}{ TRACE ELEMENT CONTENTS (ppm) } \\
\hline $\mathrm{v}$ & 267 & 308 & 267 & 195 & 297 & 280 & 290 \\
\hline $\mathrm{Cr}$ & 557 & 451 & 187 & 1089 & 290 & 214 & 327 \\
\hline $\mathrm{Ni}$ & 291 & 203 & 83 & 612 & 142 & 92 & 154 \\
\hline $\mathrm{Cu}$ & 36 & 49 & 31 & 70 & 64 & 39 & 20 \\
\hline $\mathrm{Zn}$ & 69 & 76 & 52 & 70 & 71 & 72 & 83 \\
\hline $\mathbf{R b}$ & 7 & 13 & 8 & 1 & 11 & 16 & 8 \\
\hline $\mathrm{Sr}$ & 149 & 124 & 133 & 89 & 136 & 231 & 172 \\
\hline $\mathrm{Y}$ & 15 & 24 & 23 & 18 & 23 & 26 & 26 \\
\hline $\mathrm{Zr}$ & 46 & 61 & 62 & 48 & 66 & 72 & 71 \\
\hline $\mathrm{Nb}$ & 1 & 3 & 3 & 2 & 3 & 3 & 2 \\
\hline $\mathrm{Ba}$ & 25 & 16 & 34 & 17 & 36 & 48 & 32 \\
\hline \multicolumn{8}{|c|}{ TRACE ELEMENT RATIOS } \\
\hline $\mathrm{Zr} / \mathrm{TiO}_{2}$ & 0.0057 & 0.0060 & 0.0061 & 0.0062 & 0.0065 & 0.0064 & 0.0066 \\
\hline $\mathrm{Zr} / \mathrm{Y}$ & 3.01 & 2.64 & 2.66 & 2.63 & 2.84 & 2.77 & 2.76 \\
\hline $\mathrm{Zr} / \mathrm{Nb}$ & 15.00 & 24.53 & 21.25 & 21.13 & 22 & 24 & 35.25 \\
\hline $\mathrm{Nb} / \mathrm{Y}$ & 0.09 & 0.11 & 0.13 & 0.12 & 0.13 & 0.12 & 0.08 \\
\hline
\end{tabular}

Table 5. Rare-earth element contents and primordial mantle (Wood et al., $1979 b)$ normalized ratios $((\mathrm{La} / \mathrm{Sm}) \mathrm{PM})$ and $((\mathrm{La} / \mathrm{Yb}) \mathrm{PM})$ of the basaltic rocks from Hole 768, Sulu Sea.

\begin{tabular}{lccccccc}
\hline Core-Section & $75 R-1$ & $87 R-1$ & $88 R-2$ & $94 R-1$ & $96 R-1$ & $98 R-3$ & $100 R-2$ \\
Interval $(\mathrm{cm})$ & $137-142$ & $50-53$ & $96-100$ & $72-77$ & $100-111$ & $69-72$ & $53-59$ \\
Unit. Sample \# & 1.3 & 2.14 & 3.2 & 4.4 & 5.2 & 6.1 & 8.2 \\
\hline $\mathrm{Sc}$ & 41 & 40 & 41 & 32 & 41 & 41 & 40 \\
$\mathrm{La}$ & 3.6 & 3.9 & 3.8 & 3.8 & 4 & 3.4 & 4 \\
$\mathrm{Ce}$ & 6 & 5 & 8 & 8 & 12 & 5 & 12 \\
$\mathrm{Nd}$ & 7 & 7 & 7 & 8 & 8 & 7 & 7 \\
$\mathrm{Sm}$ & 2.18 & 2.31 & 2.56 & 2.49 & 2.73 & 2.4 & 2.6 \\
$\mathrm{Eu}$ & 0.74 & 0.82 & 0.81 & 0.79 & 0.91 & 0.92 & 1 \\
$\mathrm{~Tb}$ & 0.4 & 0.5 & 0.6 & 0.6 & 0.7 & 0.6 & 0.6 \\
$\mathrm{Yb}$ & 1.49 & 1.94 & 2.67 & 2.48 & 2.53 & 2.35 & 2.57 \\
$\mathrm{Lu}$ & 0.2 & 0.27 & 0.39 & 0.36 & 0.4 & 0.3 & 0.38 \\
$\mathrm{Th}$ & 0.4 & 0.2 & 0.3 & 0.2 & 0.3 & 0.2 & 0.3 \\
$\mathrm{U}$ & 0.1 & 0.2 & 0.1 & 0.3 & 0.1 & 0.5 & 0.1 \\
$(\mathrm{La} / \mathrm{SM})_{\mathrm{PM}}$ & 0.90 & 0.92 & 0.81 & 0.83 & 0.79 & 0.77 & 0.83 \\
$\mathrm{Ca} / \mathrm{Yb})_{\mathrm{PM}}$ & 1.29 & 1.08 & 0.76 & 0.82 & 0.85 & 0.77 & 0.83 \\
\hline
\end{tabular}

diagram (Fig. 7) is based on a limited amount of data, and may not represent the full compositional range of BAT. The negative $\mathrm{Nb}$ anomalies in the multielement signatures of the Sulu Sea rocks point to a subduction related origin, the signatures themselves are most similar to BAT, and the samples lie partly in the BAT field on the $\mathrm{Cr}$ vs. Y diagram. It is concluded that the chemical characteristics of the lavas of the Sulu Sea basement are those of BAT.

The Sulu Sea basalts have a number of mineralogical and petrographic features in common with island-arc basalts (IAB). These include the presence of phenocrystic and groundmass olivine (not generally present in the groundmass of Mid-Ocean Ridge Basalts, MORB), the occurrence of orthopyroxene and clinopyroxene in the same samples (an association also generally not present in MORB's), plagioclase in the range An50-90, and inclusions of $\mathrm{Cr}$-spinel in mafic phenocrysts (see mineralogy of IAB, Table 5, Basaltic Volcanism Study Project, 1981, p. 197). Lavas erupted in volcanic arcs have high water contents as compared to those of lavas from other tectonic settings (Morris, 1989), and back-arc basalts are also characterized by water contents higher than those of MORB's (Saunders and Tarney, 1984, Fig. 3 ). The abundant vesicles, noted in all of the samples studied, with the exception of Unit 4, strongly suggest that the magmas, from which these rocks were formed, had a higher than normal initial volatile content. In addition, the trace element signatures of these rocks are most similar to those of BAT. This data suggests that the Sulu Sea formed as a back-arc basin.

Rangin (1989) has suggested that the Cagayan Ridge represents the remnant arc formed when an Oligocene to early Miocene arc rifted to form the Sulu Sea as a back-arc basin. Hole 769 penetrates the acoustic basement of the Sulu Sea which is made up of lapillistones and tuffs containing large lithic fragments of volcanic rocks.

These lithic fragments contain from $49.31 \%$ to $57.41 \% \mathrm{SiO}_{2}$ (Table 2), indicating that they are basalts, basaltic andesites, and andesites $\left(<52 \% \mathrm{SiO}_{2}, 52 \%-56 \% \mathrm{SiO}_{2}\right.$, and $56 \%-63 \% \mathrm{SiO}_{2}$, respectively, Le Maitre, 1976). The andesite shows all of the mineralogical and chemical features which are characteristic of rocks which erupted in an orogenic (volcanic arc) environment, as compiled by Bailey (1981).

It is phenocryst rich, with dominant plagioclase (labradorite), together with augite and orthopyroxene (Table 2). It has high $\mathrm{Al}_{2} \mathrm{O}_{3}$ content $(16.41 \%)$, low total iron $\mathrm{FeO}^{\mathrm{t}}(6.62 \%), \mathrm{TiO}_{2}$ $(0.89 \%), \mathrm{Zr}(106 \mathrm{ppm}), \mathrm{Y}(31 \mathrm{ppm}), \mathrm{Nb}$ (13 ppm), and low $\mathrm{Zr} / \mathrm{TiO}_{2}(0.0016), \mathrm{Nb} / \mathrm{Y}(0.42)$, and $\mathrm{Ce}(40 \mathrm{ppm})$ (Tables 2 and $7)$. The trace-element contents of the andesite from Hole 769 are much higher than those of ocean island-arc andesites (OIA) and are most like continental island-arc andesites (CIA) or andesites formed in mature ocean island arcs (Other) ( $\mathrm{La}, \mathrm{Ce}, \mathrm{Nb}$, and $\mathrm{Zr}$ contents are: 769 , andesite $18,40,13,106$ ppm, respectively; CIA, $17,37,9.4,117 \mathrm{ppm}$, respectively; Other, 11.7, 23.5, 5, $111 \mathrm{ppm}$, respectively; OIA, $3,6.9,0.81,63 \mathrm{ppm}$, respectively) (Table 7).

The major-element contents of the associated basalt and basaltic andesite clasts (Table 2) are similar to the average chemical compositions of calc-alkaline basalts $(\mathrm{CAB})$ and island arc basalts (IAB) as compiled by Condie (1985, Table 2). The absence of normative quartz and the relatively high average $\mathrm{P}_{2} \mathrm{O}_{5}(0.29 \%)$, $\mathrm{Zr}$ (95 ppm), Y (29 ppm), Nb (14 ppm), La (15.8 ppm), Ce (28 $\mathrm{ppm})$, and $\mathrm{Ni}(47 \mathrm{ppm})$ are most like those of the CAB, and the immobile element contents are all higher than those typical of IAB (Tables 2 and 7). Thus the geochemistry of the volcanic clasts recovered from Hole $769 \mathrm{C}$ suggests that they are representatives of a suite of calc-alkaline basalts, basaltic andesites, and andesites derived from a continental arc volcanic suite.

\section{Negative Ce Anomalies}

Negative $\mathrm{Ce}$ anomalies occurring in mafic volcanic rocks, or their metamorphic equivalents, are comparatively unusual and 

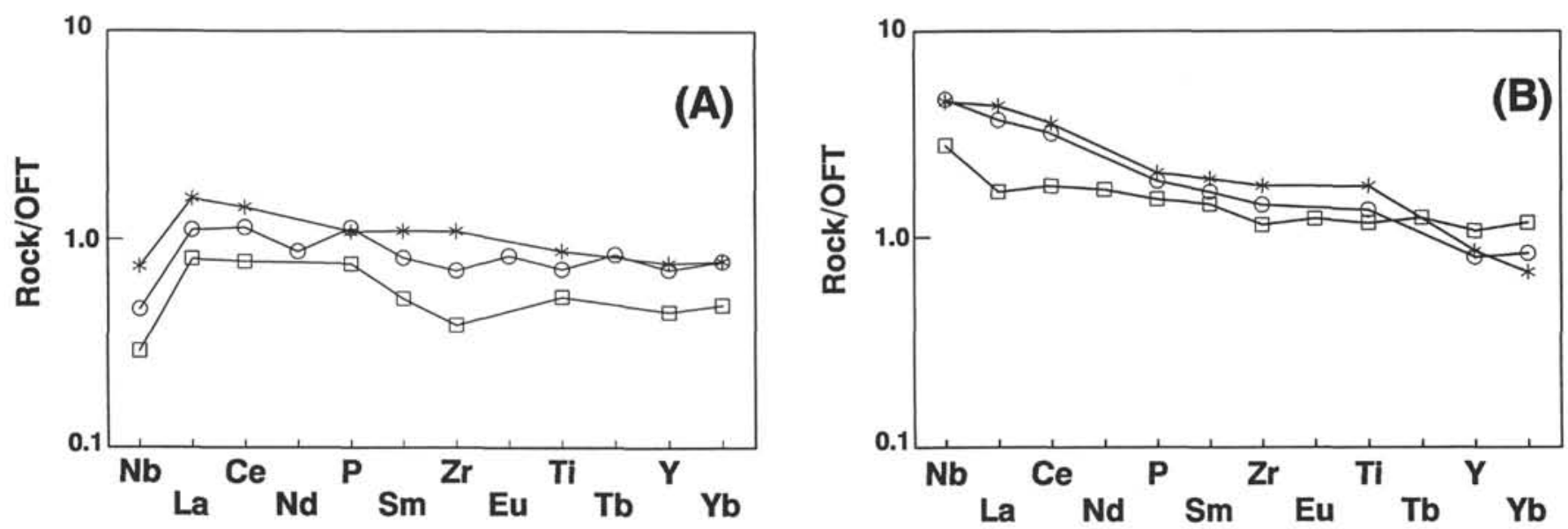

Figure 6. Ocean floor tholeiite (equivalent to N-MORB) normalized multielement plots comparing signatures of tholeiitic basalts formed in the Sulu Sea with the signatures of tholeiitic basalt and basaltic andesites suites formed in various known tectonomagmatic environments (Holm, 1985). A. Sample 8.2 (open circle), back-arc tholeiite (asterisk), low-K tholeiite (square) B. E-MORB (open circle), ocean island tholeiite (asterisk), T-MORB (square).

Table 6. A comparison of the average elemental contents and ratios of representative basaltic rocks from Hole 768, Sulu Sea, with rock suites erupted in various tectonic environments.

\begin{tabular}{lcccccccc}
\hline Unit. Sample \# & 1.3 & 8.2 & BAT & LKT & OFT & T-MORB & E-MORB & OIT \\
\hline $\mathrm{Nb}$ & 2 & 2 & 3.22 & 1.26 & 4.35 & 12.3 & 20.5 & 20 \\
$\mathrm{La}$ & 3.6 & 4 & 5.68 & 2.9 & 3.6 & 6.1 & 13.5 & 15.8 \\
$\mathrm{Ce}$ & 6 & 1 & 15 & 8.22 & 10.5 & 19 & 34 & 38 \\
$\mathrm{P}$ & 65 & 698 & 669 & 470 & 615 & 960 & 1175 & 1284 \\
$\mathrm{Zr}$ & 46 & 68 & 105 & 37 & 96 & 113 & 141 & 174 \\
$\mathrm{Sm}$ & 2.18 & 2.6 & 3.5 & 1.65 & 3.19 & 4.71 & 5.4 & 6.24 \\
$\mathrm{Ti}$ & 4856 & 6295 & 7635 & 4581 & 8704 & 10431 & 12063 & 15728 \\
$\mathrm{Y}$ & 14 & 25 & 26.8 & 15.6 & 35 & 38.4 & 28.7 & 30.7 \\
$\mathrm{Yb}$ & 1.49 & 2.57 & 2.58 & 1.58 & 3.28 & 3.94 & 2.8 & 2.27 \\
$(\mathrm{La} / \mathrm{Sm})_{\mathrm{PM}}$ & 0.90 & 0.83 & 0.88 & 0.95 & 0.61 & 0.70 & 1.36 & 1.37 \\
$(\mathrm{La} / \mathrm{Yb})_{\mathrm{PM}}$ & 1.29 & 0.83 & 1.33 & 1.11 & 0.67 & 0.83 & 2.92 & 4.15 \\
\hline
\end{tabular}

Abbreviations: OFT, mean ocean-floor tholeiites; BAT, mean back-arc tholeiites; LKT, mean low-potassium tholeiites; E-MORB, mean enriched mid-ocean ridge basalts; OIT, mean ocean-island tholeiites from Holm, 1985, Tables 2 and 3; T-MORB, transitional mid-ocean ridge basalt from Wood et al. (1979b).

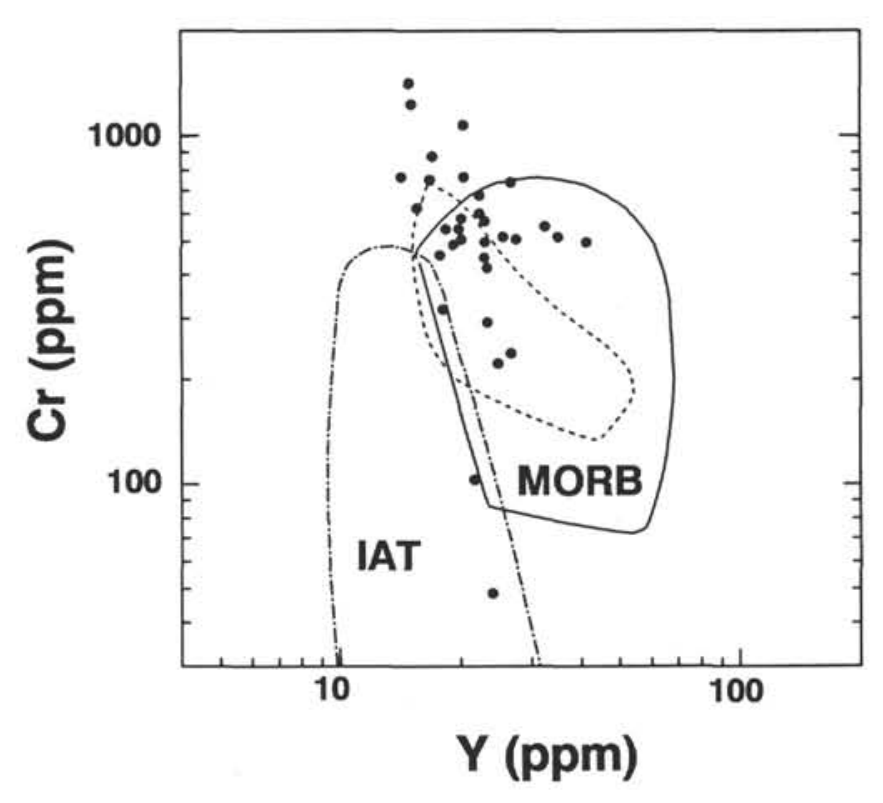

Figure 7. Crvs. Y discriminant diagram (Pearce et al., 1984) of the basalts from Hole 768, Sulu Sea. MORB and IAT fields outlined with solid lines, BAT field outlined with dashes. may result either from alteration due to interaction with seawater or from the inclusion of subducted supracrustal material in the mantle source regions of the melts (Masuda and Nagasawa, 1975; Hole et al., 1984; Meen, 1990). The basalts recovered from the basement are altered to varying degrees as a result of interaction with seawater, resulting in the replacement of primary minerals and the infilling of vesicles and fractures by clays (Table 1 ). The rocks are identified as back-arc tholeiitic basalts, the composition of which includes a subduction contribution. Thus both of the processes capable of producing negative $\mathrm{Ce}$ anomalies have affected the basement rocks. Negative $\mathrm{Nb}$ anomalies, which indicate that a subduction component has contributed to the composition of the magma from which the rocks were formed (Pearce, 1983), occur in all OFT normalized plots of the Sulu Sea basalts (e.g., Fig. 6). Ce anomalies, which vary in magnitude, may be present or absent on these plots. This lack of uniformity in the distribution of $\mathrm{Ce}$, as compared to that of $\mathrm{Nb}$, is probably not the result of the addition of a subduction component to the magma, but was caused by a less pervasive activity. The basalts show irregular variations in $\mathrm{Na}, \mathrm{K}, \mathrm{Rb}, \mathrm{Ba}$, and $\mathrm{Sr}$ that are interpreted as resulting from the mineralogical alteration caused by interaction with seawater. The amount of mineralogical and chemical alteration affecting basalts depends upon their permeability and also on the quantity of water with which they have interacted. Both of these parameters are likely to be variable in a pile of pillow basalts, breccias and sills. Thus the variable distribution of the alkali metals, $\mathrm{Sr}$ and $\mathrm{Ba}$ in the Sulu Sea basalts, is interpreted as resulting from their interac- 
Table 7. A comparison of the elemental contents and ratios of lithic clasts from Hole 769 with orogenic basalts and andesites (Condie, 1985; Bailey, 1981).

\begin{tabular}{|c|c|c|c|c|c|c|c|c|c|c|c|}
\hline $\begin{array}{l}\text { Core-Section } \\
\text { Interval (cm) } \\
\text { Lithology }\end{array}$ & $\begin{array}{c}3 R-2 \\
41-43 \\
\text { basalt }\end{array}$ & $\begin{array}{l}4 \mathrm{R}-5 \\
9-15 \\
\text { basalt }\end{array}$ & $\begin{array}{c}\text { 5R-5 } \\
22-25 \\
\text { basaltic } \\
\text { andesite }\end{array}$ & $\begin{array}{c}7 \mathrm{R}-1 \\
108-112 \\
\text { basaltic } \\
\text { andesite }\end{array}$ & $\begin{array}{c}9 \mathrm{R}-3 \\
116-120 \\
\text { andesite }\end{array}$ & $\begin{array}{c}9 \mathrm{R}-4 \\
46-49 \\
\text { basalt }\end{array}$ & $\begin{array}{c}\text { IAB } \\
\text { basalt }\end{array}$ & $\begin{array}{c}\text { CAB } \\
\text { basalt }\end{array}$ & $\begin{array}{c}\text { OIA } \\
\text { andesite }\end{array}$ & $\begin{array}{c}\text { Other } \\
\text { andesite }\end{array}$ & $\begin{array}{c}\text { CIA } \\
\text { andesite }\end{array}$ \\
\hline V & 232 & 343 & 262 & 229 & 239 & 257 & 253 & 226 & 197 & 170 & 135 \\
\hline $\mathrm{Cr}$ & 88 & 206 & 47 & 64 & 45 & 65 & 145 & 100 & 10 & 23 & 37 \\
\hline Co & 59 & 50 & 61 & 69 & 46 & 36 & 32 & 30 & 25 & 20 & 19 \\
\hline $\mathrm{Ni}$ & 73 & 66 & 28 & 34 & 25 & 35 & 30 & 50 & 7 & 18 & 21 \\
\hline $\mathrm{Cu}$ & 48 & 31 & 43 & 46 & 35 & 28 & 990 & 80 & 55 & 53 & 35 \\
\hline $\mathrm{Zn}$ & 112 & 83 & 74 & 77 & 75 & 74 & 81 & 80 & 90 & 74 & 88 \\
\hline $\mathbf{R b}$ & 15 & 38 & 19 & 32 & 38 & 18 & 8 & 20 & 8.3 & 28 & 44 \\
\hline $\mathrm{Sr}$ & 359 & 299 & 282 & 282 & 250 & 312 & 260 & 525 & 220 & 434 & 400 \\
\hline $\mathbf{Y}$ & 24 & 33 & 32 & 27 & 31 & 31 & 21 & 25 & 25 & 20 & 22 \\
\hline $\mathrm{Zr}$ & 56 & 92 & 117 & 100 & 106 & 111 & 55 & 140 & 63 & 111 & 117 \\
\hline $\mathrm{Nb}$ & 6 & 22 & 11 & 15 & 13 & 14 & 2 & 5 & 0.81 & 5 & 9.4 \\
\hline $\mathrm{Ba}$ & 84 & 201 & 235 & 284 & 269 & 223 & 125 & 350 & 152 & 318 & 395 \\
\hline $\mathrm{Pb}$ & 25 & 21 & 31 & 27 & 27 & 27 & 2.9 & 5 & 10.4 & & \\
\hline La & 16 & 15 & 19 & 10 & 18 & 19 & 3 & 10 & 3 & 11.7 & 17 \\
\hline $\mathrm{Ce}$ & 30 & 25 & 28 & 27 & 40 & 30 & 6.9 & 23.5 & 37 & & \\
\hline $\mathrm{Zr} / \mathrm{TiO}_{2}$ & 0.0089 & 0.0079 & 0.0118 & 0.0112 & 0.0119 & 0.0114 & 0.0025 & 0.0025 & 0.0244 & 0.0411 & 0.0424 \\
\hline $\mathrm{Zr} / \mathrm{Y}$ & 2.33 & 2.79 & 3.66 & 3.7 & 3.42 & 3.58 & 2.62 & 5.64 & 2.2 & 4.7 & 5.4 \\
\hline $\mathrm{Zr} / \mathrm{Nb}$ & 9.33 & 4.18 & 10.64 & 6.67 & 8.15 & 7.93 & 27.5 & 5 & 77.78 & 22.2 & 12.45 \\
\hline $\mathrm{Nb} / \mathrm{Y}$ & 0.25 & 0.67 & 0.34 & 0.56 & 0.42 & 0.45 & 0.095 & 0.2 & 0.03 & 0.25 & 0.43 \\
\hline
\end{tabular}

tion with seawater. Similarly, the lack of uniform distribution of $\mathrm{Ce}$ in the basalts is considered to be the result of their interaction with seawater, and not the result of the addition of a subductionrelated supracrustal component.

\section{PETROGENESIS}

Petrogenetic modeling of the Sulu Sea basalts provides some understanding of the physical conditions and processes of their formation, as well as information about the mineralogical and chemical composition of the source(s) from which they were derived. In this section we show that the Sulu Sea basalts cannot be derived from a homogeneous source but require contributions from a heterogeneous mantle and from a subduction component. The immobile trace element ratios of all of the Sulu Sea rocks are very similar as shown by REE element and multielement plots (Figs. 4 and 5). This suggests that all of these basalts were derived from a common source and are genetically related (Thompson et al., 1983). The suite shows systematic increases in concentrations of incompatible elements (i.e., $\mathrm{Ti}, \mathrm{Zr}, \mathrm{Y}$ ) and decreases in compatible element concentrations (i.e., $\mathrm{Ni}$ ) with decreasing $\mathrm{Mg}$-numbers (Fig. 3, Tables 3 and 4). These can be accounted for in terms of different degrees of partial melting and/or fractional crystallization and the rocks are treated as a single suite. There are, however, small differences in the relative concentrations of the LREE as compared to the HFSE and HREE (La/YbPM, Fig. 10, Table 6) which, as discussed below, cannot be readily accounted for in the petrological modeling. The distribution coefficients used in the modeling are given in Table 8 .

The rocks of Unit 4 have the higher $\mathrm{Mg}$-numbers and $\mathrm{Ni}$ and $\mathrm{Cr}$ contents than any other unit in the suite but are not used as a starting point for petrological modeling. This is because their crystallization history is poorly understood, and they are not typical of the remainder of the sequence.

Unit 1 has mineralogical and chemical characteristics that are typical of the majority of the units in the core, and is considered to be representative of the volcanic sequence. It is made up of vesicular pillow basalts, exhibiting low-pressure mineralogy (olivine, clinopyroxene, plagioclase), and quench textures. The unit also has a very high $\mathrm{Mg}$-numbers (average 77), low average $\mathrm{TiO}_{2}$ $(0.82 \%), \mathrm{P}_{2} \mathrm{O}_{5}(0.16 \%)$, and $\mathrm{Zr}(46 \mathrm{ppm})$ contents, and high average $\mathrm{Ni}(291 \mathrm{ppm})$ and $\mathrm{Cr}(557 \mathrm{ppm})$ contents. The high
Table 8. Distribution coefficients used in the modeling calculations.

\begin{tabular}{lcccccccr}
\hline & Ol & Opx & \multicolumn{1}{c}{ Cpx } & Pl & Gnt & \multicolumn{1}{c}{ Spl } & Hbd & Mgt \\
\hline $\mathrm{La}$ & 0.00001 & 0.007 & 0.070 & 0.150 & 0.030 & 0.000 & 0.200 & 0.000 \\
$\mathrm{Ce}$ & 0.00001 & 0.008 & 0.100 & 0.120 & 0.030 & 0.000 & 0.260 & 0.000 \\
$\mathrm{Nd}$ & 0.00007 & 0.010 & 0.220 & 0.081 & 0.087 & 0.000 & 0.400 & 0.000 \\
$\mathrm{Sm}$ & 0.00060 & 0.020 & 0.400 & 0.067 & 0.220 & 0.000 & 0.700 & 0.000 \\
$\mathrm{Eu}$ & 0.00100 & 0.020 & 0.400 & 0.350 & 1.000 & 0.001 & 0.800 & 0.000 \\
$\mathrm{~Tb}$ & 0.00200 & 0.050 & 0.500 & 0.060 & 3.000 & 0.002 & 0.800 & 0.000 \\
$\mathrm{Yb}$ & 0.02000 & 0.150 & 0.600 & 0.070 & 5.000 & 0.020 & 0.600 & 0.000 \\
$\mathrm{Lu}$ & 0.01600 & 0.180 & 0.600 & 0.060 & 5.500 & 0.016 & 0.500 & 0.000 \\
$\mathrm{Y}$ & 0.01000 & 0.010 & 0.200 & 0.030 & 2.000 & 0.010 & 1.000 & 0.200 \\
$\mathrm{Zr}$ & 0.01000 & 0.030 & 0.030 & 0.010 & 0.300 & 0.010 & 1.500 & 0.100 \\
$\mathrm{Nb}$ & 0.01000 & 0.010 & 0.020 & 0.010 & 0.100 & 0.010 & 0.800 & 0.400 \\
$\mathrm{Ti}$ & 0.02000 & 0.100 & 0.180 & 0.040 & 0.300 & 0.800 & 1.500 & 7.500 \\
$\mathrm{Ni}$ & 5.00000 & 3.100 & 2.500 & 0.000 & 5.100 & 16.000 & 7.000 & 30.000 \\
$\mathrm{Cr}$ & 0.10000 & 5.000 & 15.000 & 0.000 & 17.500 & 600.000 & 15.000 & 150.000 \\
$\mathrm{Sc}$ & 0.16000 & 0.160 & 0.510 & 0.040 & 2.270 & 2.000 & 1.500 & 2.000 \\
\hline
\end{tabular}

Data from Arth (1976), Irving (1978), Pearce and Norry (1979), and Condie (pers. comm.).

$\mathrm{Mg}$-numbers and $\mathrm{Ni}$ and $\mathrm{Cr}$ contents of the rocks of this unit are similar to those expected in unevolved tholeiitic partial melts, which have been little modified by fractional crystallization and other processes. The rocks of this unit are suitable as a starting point in petrological modeling. Sample 1.3 has the lowest immobile incompatible element contents within the unit (Tables 3,4 , and 5), and its composition is used as the most primitive rock in the petrogenetic modeling below. The systematic increase in incompatible element contents, with decrease in $\mathrm{Mg}$-number within the suite (Fig. 3), suggests that the rocks of the sequence are related by fractional crystallization.

A wide variety of types of models, mineralogical and chemical compositions, and melting proportions were tested employing interactive computer programs (Holm, 1988; Holm, in press). This showed that the compositions of the Sulu Sea rocks could be adequately accounted for in terms of simple batch partial melting and fractional crystallization, and that there was no need to invoke more complex processes. Initially modeling was carried out using the source mineral compositions and melting proportions described by Condie (1985) and Pearce (1983) and primordial mantle (Wood et al., 1979b) and chondrite (Wakita et al., 1971) traceelement compositions. The $\mathrm{MgO}$ and $\mathrm{FeOt}$ contents, and the dis- 
tribution of $\mathrm{Ni}, \mathrm{Cr}$, and $\mathrm{Zr}$ (Leeman, 1976; Hanson and Langmuir, 1978; Rajamani et al., 1985) suggest that Unit 1 was formed by approximately $20 \%$ partial melting of an ultramafic source at approximately $1325^{\circ} \mathrm{C}$. Sample 8.2 requires $15 \%$ partial melting of the same source at about $1300^{\circ} \mathrm{C}$, followed by $5 \%$ removal of olivine by fractional crystallization. These constraints require modifications of the primordial mantle trace-element composition (LREE-enrichment and Y-and Ti-depletion as compared to Wood et al., $1979 \mathrm{~b}$ original values), and minor changes to the modal mineralogy and melting proportions for each rock modeled (see caption Fig. 8), to achieve a good match between the measured and modeled compositions. The REE patterns are slightly LREE depleted to slightly LREE enriched (Sample 1.3 (La/Yb)PM 1.29, Sample $8.2(\mathrm{La} / \mathrm{Yb}) \mathrm{PM} 0.83$, Table 5) and point to partial melting of a MORB-like spinel lherzolite source (Pearce, 1983). The Ni and $\mathrm{Cr}$ contents are most readily produced when a small amount of spinel remains in the residue after the melt has been generated.

Using these constraints the detailed modeling suggests that sample 1.3 formed by $20 \%$ partial melting of an ultramafic source (60\% olivine, $20 \%$ orthopyroxene, $14.5 \%$ clinopyroxene, and $5.5 \%$ spinel) leaving a refractory residue comprising $72 \%$ olivine, $20 \%$ orthopyroxene, $8 \%$ clinopyroxene, and $1 \%$ spinel. A precise match of the trace-element signature of sample 1.3 (Table 6) would require the increase of the hypothetical (primordial mantle) source contents of LREE (Nd, Sm and Eu), and depletion in HFSE (Y, Zr, Nb, and Ti) (see caption Fig. 8 for model details). Such enrichments and depletions are characteristic of the sources of island arc lavas.

The trace-element composition of sample 8.2, the most evolved of the samples analyzed (Mg-number 63.88, $\mathrm{Zr} 68 \mathrm{ppm}$, Ni $176 \mathrm{ppm}$ ), can be matched by $15 \%$ partial melting followed by $5 \%$ crystal fractionation of olivine. The refractory residue of this process comprises $68 \%$ olivine, $20 \%$ orthopyroxene, $11 \%$ clinopyroxene, and $1 \%$ spinel. In this case a precise match between model and rock can be achieved by depletion of the primordial mantle source in $\mathrm{La}, \mathrm{Ce}, \mathrm{Nd}, \mathrm{Y}, \mathrm{Nb}$, and $\mathrm{Ti}$, and some enrichment in $\mathrm{Sm}, \mathrm{Eu}, \mathrm{Tb}, \mathrm{Yb}$, and $\mathrm{Lu}$ (see Fig. 8 caption for details). LREE depletion is characteristic of MORB's and depletion of HFSE is characteristic of subduction-related rocks, suggesting that the final composition of the melt results from contributions from more than one source.

There are very small differences in the relative fractionation of the REE in the Sulu Sea samples, but all of these rocks have the characteristic trace-element signatures of back-arc tholeiites (HFSE depletion in particular). Rock suites formed in association with subduction zones are commonly regarded as very complicated systems involving mixtures of many materials (slab, sediment, different types of mantle and crust) (Pearce, 1983; Hawkesworth et al., 1984; Thompson et al., 1984, 1986; Arculus and Powell, 1986; Hickey et al., 1986; Carlson, 1987; Morris, 1989). In many studies small differences in LREE distribution of the type occurring between the unevolved and evolved Sulu Sea basalts have been explained as resulting from differences in amount and composition of the subduction component. However, current work, based on Be isotopes and B content (Morris, 1989), favors the view that the subduction-related lava component is probably an aqueous solution rather than a melt or solid. This solution has a nearly constant composition and cannot be used to account for the complexity of volcanic arc suites. Thus, the differences in the trace-element patterns of the unevolved and evolved Sulu Sea rocks must be explained in terms of a chemically variable mantle and/or interaction of magmas with the crust during ascent.

There is geophysical and geological evidence (Rangin, 1989) that suggests that the acoustic basement of Hole 769 overlies continental crust. The occurrence of a suite of calc-alkaline basaltic and andesitic lithic clasts derived from this basement supports the contention that the Cagayan Ridge represents the remains of a volcanic island arc formed upon continental crust. In this scenario the Sulu Sea formed by rifting of pre-existing continental crust and the basalts forming its basement must have been derived largely from heterogeneous sub-continental lithosphere (Harte, 1983) and variable contributions from a subduction component (LREE and HFSE depletion). This would explain the complexity of the trace-element composition of the basaltic rocks recovered from Hole $768 \mathrm{C}$.
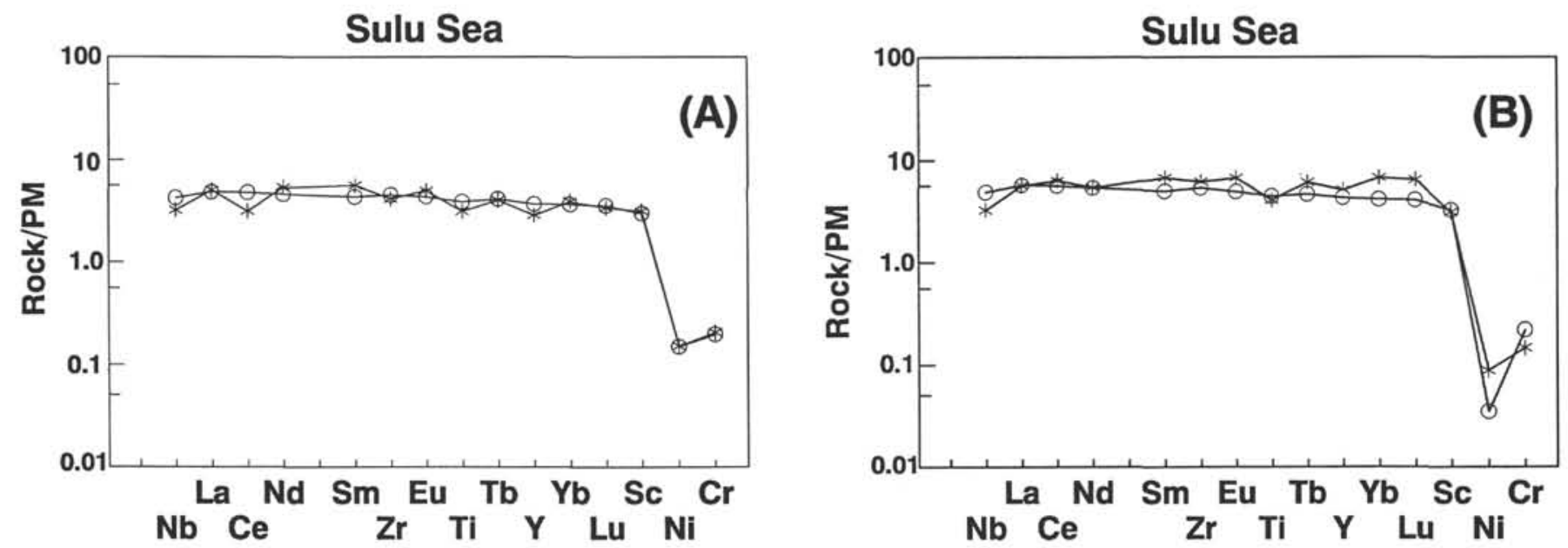

Figure 8. Primordial mantle (Wood et al., 1979b) normalized multielement plots comparing modeled and measured compositions. Both models start with a source comprising $60 \%$ olivine, $20 \%$ orthopyroxene, $14.5 \%$ clinopyroxene, and 5.5\% spinel. A. Sample 1.3 (asterisk), modeled values (open circles). Temperature approximately $135^{\circ} \mathrm{C}$; modal melting olivine $14 \%$, orthopyroxene $20 \%$, clinopyroxene $41 \%$, spinel $25 \%$; refractory residue olivine $72 \%$, orthopyroxene $20 \%$, clinopyroxene $8 \%$, spinel $1 \%$. An exact match can be achieved where elements La to Eu are enriched by factors of 1.05 to 1.3 , and $\mathrm{Y}$ to Ti are depleted by factors of 0.6 to 0.9 times those of the hypothetical primordial mantle source. B. Sample 8.2 (asterisk), modeled values (open circles). Temperature approximately $130^{\circ} \mathrm{C}$; modal melting olivine $14 \%$, orthopyroxene $20 \%$, clinopyroxene $36 \%$, spinel $30 \%$; refractory residue olivine $68 \%$, orthopyroxene $20 \%$, clinopyroxene $18 \%$, spinel $1 \%$. An exact match can be achieved where La to $\mathrm{Nd}$ ratios are slightly depleted $(0.85$ to 0.95$)$ along with $\mathrm{Y}(0.86), \mathrm{Nb}(0.5)$, and $\mathrm{Ti}(0.8)$, and $\mathrm{Sm}$ to $\mathrm{Lu}$ ratios are enriched 1.2 to 1.55 times as compared to the composition of the hypothetical primordial mantle source. 


\section{DISCUSSION}

The geochemistry of the basaltic rocks of the basement of the Sulu Sea has been shown to be most similar to that of BAT. Their complex trace element chemistry is best explained in terms of contributions from a heterogenous sub-continental lithosphere combined with variable amounts of an aqueous subduction component. The lithic clasts from the pyroclastic rocks that, represent the acoustic basement of the Cagayan Ridge, have the geochemical characteristics of calc-alkaline basalt-andesite sequences. Such suites typically erupt in continental margin volcanic arcs or in mature island arcs formed on thick crust.

These conclusions indicate that the Sulu Sea formed as a back-arc basin by rifting of a pre-existing island arc that most probably formed upon continental crust. The sedimentary sequence in Hole $768 \mathrm{C}$ indicates that the Sulu Sea opened rapidly in the late early Miocene. The lack of volcanogenic sediments above the pyroclastic basement in Hole 769 indicates the cessation of orogenic volcanic activity along the Cagayan Ridge (Rangin et al., 1989). The brown claystones at the base of each section are of essentially the same age, showing that the opening of the Sulu Sea and the cessation of volcanism on the Cagayan Ridge were approximately coeval.

These conclusions confirm the contention (Rangin, 1989) that the Sulu Sea is not a trapped relic of pre-existing oceanic crust (Lee and McCabe, 1986), but formed as a back-arc basin, and provides additional evidence on which to base the interpretation of the tectonic structure of this complex area. The opening of the Sulu Sea Basin is contemporaneous with the cessation of volcanism on the Cagayan Ridge. It is highly improbable that the basin originated as a result of southward subduction beneath the ridge. The temporal relationships can best be explained if the basin originated by rifting related to the northward subduction of the Celebes Plate beneath an Oligocene to early Miocene arc located in the present position of the active Sulu arc (Rangin, 1989), leaving the Cagayan Ridge as a remnant arc. The confirmation that the Sulu Sea was formed by back-arc rifting provides further strong support for Rangin's (1989) tectonic reconstruction of this complex area.

\section{CONCLUSIONS}

The volcanic rocks forming the basement of the Sulu Sea are identified as a sequence of back-arc tholeiitic basalts that erupted during the early middle Miocene. Continental orogenic volcanism, which had been previously active on the Cagayan Ridge, ceased more or less simultaneously with the eruption of the back-arc tholeiites. These relationships indicate that the Sulu Sea formed as a back-arc basin by rifting of a pre-existing Oligocene to early Miocene continental margin (?) volcanic arc, leaving the Cagayan Ridge as a remnant arc. The age of the basin and its geological relationships strongly suggest that it formed as a result of the northward subduction of the Celebes Sea Plate.

\section{ACKNOWLEDGMENTS}

We wish to thank the Natural Sciences and Engineering Research Council of Canada for providing funds for this study, and Drs. M. Fisk, R. Taylor, and T. Alabaster for their helpful reviews of the manuscript.

\section{REFERENCES}

Abbott, P. L., and Smith, T. E., 1978. Trace element comparison of clasts in Eocene conglomerates, southwestern California and northwestern Mexico. J. Geol., 86:753-762.

Arculus, R. J., and Powell, R., 1986. Source component mixing in the regions of arc magma generation. J. Geophys. Res., 91, B6:59135926.
Arth, J. G., 1976. Behavior of trace elements during magmatic processes: a summary of theoretical models and their applications. J. Res. U.S. Geol. Surv., 4:41-47.

Bailey, J. C., 1981. Geochemical criteria for a refined tectonic discrimination of orogenic andesites. Chem. Geol., 32:139-154.

Basaltic Volcanism Study Project, 1981. Basaltic Volcanism on the Terrestrial Planets: New York (Pergamon Press).

Beswick, A. E., and Soucie, G., 1978. A correction procedure for metasomatism in Archean greenstone belts. Precambrian Res., 6:235-248.

Carlson, R. W., 1987. Geochemical evolution of the crust and mantle. Rev. Geophys., 25:1011-1020.

Condie, K. C., 1981. Archean greenstone belts. Developments in Precambrian Geology (Vol. 3): New York (Elsevier).

1985. Secular variation in the composition of basalts: an index to mantle evolution. J. Petrol., 26:545-563.

Condie, K. C., Bowling, G. P., and Vance, R. K., 1985. Geochemistry and origin of the early Proterozoic rocks, Dos Cabezas Mountains, southeastern Arizona. Geol. Soc. Am. Bull., 96:655-662.

Floyd, P. A., and Winchester, J. A., 1978. Identification and discrimination of altered and metamorphosed volcanic rocks using immobile elements. Chem. Geol., 21:291-306.

Gelinas, L. Mellinger, M. and Trudel, P., 1982. Archean mafic metavolcanics from the Rouyn-Noranda district, Abitibi Greenstone Belt, Quebec. 1. Mobility of the major elements. Can. J. Earth Sci., 19:2258-2275.

Hanson, G. N., and Langmuir, C. H., 1978. Modelling of major elements in mantle-melt systems using trace element approaches. Geochim. Cosmochim. Acta, 42:725-741.

Harte, B., 1983. Mantle peridotites and processes - the Kimberlite sample. In Hawkesworth, C. D., and Norry, M. J. (Eds.), Continental Basalts and Mantle Xenoliths: London (Shiva Publications, Ltd.), 46-91.

Hawkesworth, C. J., Rogers, N. W., van Calsteren, P. W. C., and Menzies, M. A., 1984. Mantle enrichment processes. Nature, 311:331-335.

Hickey, R. L., Frey, F. A., Gerlach, D. C., and Lopez-Escobar, L., 1986. Multiple sources of basaltic rocks from the southern volcanic zone of the Andes $\left(34^{\circ}-41^{\circ}\right)$ : trace element and isotopic evidence for contributions from subducted oceanic crust, mantle, and continental crust. J. Geophys. Res., 91:5963-5983.

Hole, M., Saunders, A. D., Mariner, G. F., and Tarney, J., 1984. Subduction of pelagic sediments: implications for the origin of $\mathrm{Ce}$-anomalous basalts from the Mariana Islands. J. Geol. Soc. London, 141:453-472.

Holm, P. E., 1985. The geochemical fingerprints of different tectonomagmatic environments using hygromagmatophile element abundances of tholeiitic basalts and basaltic andesites. Chem. Geol., 51:303-323.

1988. Petrogenetic modeling with a spreadsheet program. $J$. Geol. Ed., 36:155-156.

in press. Complex petrogenetic modeling using spreadsheet software. Computers and Geosciences.

Huang, C. H., and Smith, T. E., 1983. Application of the linear relationship between the reciprocal of the analyte-line intensity and the reciprocal of concentration to the analysis of geological materials. $X$-ray Spectrom.,12:87-90.

Irving, A. J., 1978. A review of experimental studies of crystal/liquid trace element partitioning. Geochim. Cosmochim. Acta, 42:743-770.

Kokelaar, B. P., Howells, M. F., Bevins, R. E., Roach, R. A., and Dunkley, P. N., 1984. The Ordovician marginal basin of Wales. In Kokelaar, B. P., and Howells, M. F. (Eds.), Marginal Basin Geology. Geol. Soc. London Spec. Publ., 16:245-270.

Lee, C. S., and McCabe, R., 1986. The Banda-Celebes-Sulu basin: a trapped piece of Cretaceous oceanic crust? Nature, 322:51-54.

Leeman, W. P., 1976. Petrogenesis of McKInney (Snake River) olivine tholeiite in the light of rare earth and $\mathrm{Cr} / \mathrm{Ni}$ distributions. Geol. Soc. Am. Bull., 87:1582-1586.

Le Maitre, R. W., 1976. The chemical variability of some common igneous rocks. J. Petrol., 17:589-637.

Ludden, J., Gelinas, L. and Trudel, P., 1982. Archean metavolcanics from the Rouyn-Noranda district, Abitibi Greenstone Belt, Quebec. 2. Mobility of trace elements and petrogenetic constraints. Can.J. Earth Sci., 19:2276-2287.

Masuda, A., and Nagasawa, S., 1975. Rocks with negative cerium anomalies, dredged from Shatsky Rise. Geochem. J., 9:227-233.

Meen, J. K., 1990. Negative Ce anomalies in the Archean amphibolites and Laramide granitoids, southwestern Monyana, USA. Chem. Geol., 81:191-207. 
Morris, J., 1989. Subduction, volcanism, and change in the earth. Carnegie Institution of Washington Yearbook, 88:116-122.

Pearce, J. A., 1983. Role of the sub-continental lithosphere in magma genesis at active continental margins. In Hawkesworth, C. J., and Norry, M. J. (Eds.), Continental Basalts and Mantle Xenoliths: Cheshire, U.K. (Shiva Publishing Ltd.), 230-249.

Pearce, J. A., and Norry, M. J., 1979. Petrogenetic implications of Ti, Zr, $\mathrm{Y}$, and $\mathrm{Nb}$ variations in volcanic rocks. Contrib. Mineral. Petrol., 69:33-47.

Pearce, J. A., Lippard, S. J., and Roberts, S., 1984. Characteristics and tectonic significance of supra-subduction zone ophiolites. In Kokelaar, B. P., and Howells, M. F. (Eds.), Marginal Basin Geology. Geol. Soc. London Spec. Publ., 16:59-76.

Peck, D. C., and Smith, T. E., 1989. The geology and geochemistry of an early Proterozoic volcanic-arc association at Cartwright Lake: Lynn Lake Greenstone Belt, Northwestern Manitoba. Can. J. Earth Sci., 26:716-736.

Rajamani, V., Shivkumar, K., Hanson, G. N., and Shirey, S. B., 1985. Geochemistry and petrogenesis of amphibolites, Kolar Schist, South India: evidence for komatiitic magma derived from low percentages of melting of the mantle. J.Petrol., 26:92-123.

Rangin, C., 1989. The Sulu Sea, a back-arc basin setting within a Neogene collision zone. Tectonophysics, 161:119-141.

Rangin, C., Silver, E. A., et l'equipe du leg 124., 1989. Forages dans les bassins marginaux du SE. Asiatique: resultats preliminaires du leg 124 (Ocean Drilling Program). C. R. Acad. Sci., Paris, Ser. 2, 1333-1339.

Rautenschlien, M., Jenner, G. A., Hertogen, J., Hoffmann, A. W., Kerrich, R., Schmincke, H. U., and White, W. M., 1985. Isotopic and trace element composition of volcanic glasses from Akaki Canyon, Cyprus: implications for the origin of the Troodos ophiolite. Earth Planet. Sci. Lett., 75:369-383.

Saunders, A. D., and Tarney, J., 1984. Geochemical characteristics of basaltic volcanism within back-arc basins. In Kokelaar, B. P., and Howells, M. F. (Eds.), Marginal Basin Geology. Geol. Soc. London Spec. Publ., 16:59-76.

Shipboard Scientific Party, 1990. In Rangin, C., Silver, E. A., von Breymann, M. T., et al., Proc. ODP, Init. Repts., 124: College Station, TX (Ocean Drilling Program).

Taylor, B., and Karner, G. D., 1983. On the evolution of marginal basins. Rev. Geophys. Space Phys., 21:1727-1741.
Taylor, S. R., 1969. Trace element chemistry of andesites and associated calc-alkaline rocks. McBirney, A. R. (Ed.), Proc. Andesite Conf., Bull. Oregon Dept. Geol. Miner. Ind., 65:43-64.

Thompson, R. N., Morrison, M. A., Dickin, A. P., and Hendry, G. L., 1983. Continental flood basalts .... arachnids rule. In Hawkesworth, C. J., and Norry, M. J. (Eds.), Continental Basalts and Mantle Xenoliths: London (Shiva Publications, Ltd.), 158-185.

Thompson, R. N., Morrison, M. A., Hendry, G. L., and Parry, S. J., 1984. An assessment of the relative roles of crust and mantle in magma genesis: an elemental approach. Phil. Trans. Roy. Soc. London, A310:549-590.

Thompson, R. N., Morrison, M. A., Dickin, A. P., Gibson, I. L., and Harmon, R. S., 1986. Two contrasting styles of interaction between basic magmas and continental crust in the British Tertiary Volcanic Province. J. Geophys. Res., 91:B6:5985-5997.

Ulmer, P., 1988. High pressure phase equilibria of a calc-alkaline picrobasalt: implication for the genesis of calc-alkaline magmas. Ann. Rept., Director of the Geophysical Laboratory, Carnegie Institution of Washington, 1987-1988, 28-35.

1989. Partitioning of high field strength elements among olivine, pyroxenes, garnet and calc-alkaline picrobasalt: experimental results and an application. Annual report of the Director of the Geophysical Laboratory Carnegie Institution, Washington, 1988-1989. Geophysical Laboratory, Washington, DC, 42-47.

Wakita, H., Rey, P., and Schmitt, R. A., 1971. Abundances of the 14 rare-earth elements and 12 other trace-elements in Apollo 12 samples: five igneous and one breccia rocks and four soils. Proc. 2nd Lunar Sci. Conf., 1319-1329.

Wood, D. A., Joron, L. L., Treuil, M., Norry, M., and Tarney, J., 1979a. Elemental and $\mathrm{Sr}$ isotope variations in basic lavas from Iceland and the surrounding ocean floor. Contrib. Mineral. Petrol., 70:319-339.

Wood, D. A., Joron, J. L., and Treuil, M., 1979b. A re-appraisal of the use of trace elements to classify and discriminate between magma series erupted in different tectonic settings. Earth Planet. Sci. Lett., 45:326-336.

Date of initial receipt: 6 June 1990

Date of acceptance: 11 November 1990

Ms 124B-159 